

\title{
The Nature and Basic Problems of Compliance Regimes
}

\author{
Dr. Marc Engelhart
}

Freiburg im Breisgau 2018 
Contributions to Security Law/3

(Beiträge zum Sicherheitsrecht/3)

Edited by Marc Engelhart

The series entitled "Contributions to Security Law" is a venue that provides open access to important research findings for a broad spectrum of professionals. The findings are the results of projects, including ongoing projects, that emerged from the Otto-Hahn-Group on the "Architecture of Security Law" (ArchiS) or are projects of individual group members. The papers are available both online in PDF format on the websites of the Max Planck Institute for Foreign and International Criminal Law (https://www.mpicc.de) and the research group (https://criminallaw.science) as well as in print.

Bibliografische Information der Deutschen Nationalbibliothek

Die Deutsche Nationalbibliothek verzeichnet diese Publikation in der Deutschen Nationalbibliografie; detaillierte bibliografische Daten sind im Internet über http://dnb.d-nb.de abrufbar.

Alle Rechte vorbehalten

C 2018 Max-Planck-Gesellschaft zur Förderung der Wissenschaften e.V. c/o Max-Planck-Institut für ausländisches und internationales Strafrecht, Forschungsgruppe „Architektur des Sicherheitsrechts“(ArchiS)

Günterstalstraße 73, 79100 Freiburg i.Br.

Umschlagbild: (c) (v.1.n.r.) kyolshin, iStock; Flying Colours Ltd., Getty Images; tirc83, iStock [obere Reihe];

NSA, www.nsa.gov; mthaler, iStock [untere Reihe]

Satz und Layout: Dorothea Borner-Burger

Druck: Stückle Druck und Verlag, Stückle-Straße 1, 77955 Ettenheim

ISBN 978-3-86113-783-2

DOI https://doi.org/10.30709/archis-2018-3 


\section{Contents}

List of Abbreviations ........................................................................................... III

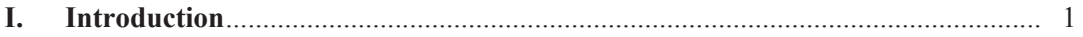

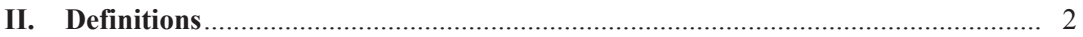

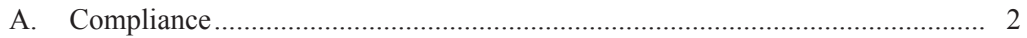

B. Compliance Program ............................................................................. 2

C. Compliance Investigations........................................................................ 3

III. Relevance of Compliance Programs................................................................ 3

A. Development of the Compliance Movement ................................................. 3

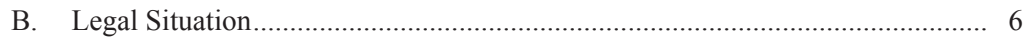

1. Responsibility ............................................................................ 7

a) Direct Compliance Obligations ................................................... 7

b) Indirect Compliance Obligations in Corporate/Civil Law ............... 7

c) Indirect Compliance Obligations in the Law of Public Sanctions .......................................................................... 8

d) Indirect Compliance Obligations in Corporate Criminal Liability Laws .............................................................................. 10

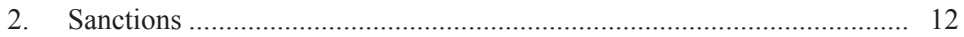

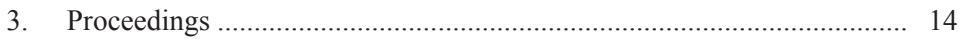

C. Compliance Program ................................................................................... 16

D. Compliance Investigations........................................................................ 19

IV. Compliance Between Regulation and Self-Regulation .................................... 21

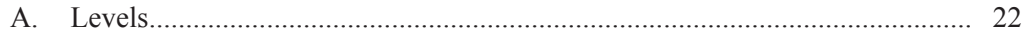

1. Self-Regulation....................................................................... 22

a) Pure Self-Regulation ........................................................... 22

b) "Requirements" of Private Institutions........................................... 23

2. Informal State Support ....................................................................... 24

a) National System ..................................................................... 24

b) Supranational System ............................................................. 24

3. Rewarding Compliance .................................................................... 26

4. Sanctioning the Lack of Compliance ..................................................... 28

5. Excluding Responsibility................................................................. 28

6. General Obligation to Implement Compliance Programs ...................... 29 
B. Towards a General Compliance Theory ….............................................. 30

1. Self-Regulation and its Limits............................................................. 30

2. Compliance as Regulated Self-Regulation ........................................... 32

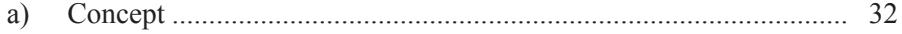

b) The Use of Criminal Law ......................................................... 35

c) Limits and Problems .............................................................. 36

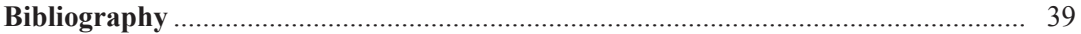




\section{List of Abbreviations}

AktG

Am. Crim. L. Rev.

BaFin

BB

BGB1

BGHSt

BImSchG

$\mathrm{CCZ}$

DB

Del. J. Corp. L.

Doc.

ed./eds.

edn.

EPA

FSA

GA

Geo. L. J.

GewO

HGB

HRC

IDW

JSt

$\mathrm{JZ}$

KritV

KJ

KWG

L. Rev.

MschrKrim

NZG
Aktiengesetz

American Criminal Law Review

Bundesanstalt für Finanzdienstleistungsaufsicht

Der Betriebs-Berater

Bundesgesetzblatt

Entscheidungssammlung des Bundesgerichtshofs in Strafsachen

Bundesimmissionsschutzgesetz

Corporate Compliance Zeitschrift

Der Betrieb

Delaware Journal of Corporate Law

Document

editor/editors

edition

US Environmental Protection Agency

Financial Sector Act

Goltdammer's Archiv für Strafrecht

The Georgetown Law Journal

Gewerbeordnung

Handelsgesetzbuch

Human Rights Council

Institut der Wirtschaftsprüfer e.V.

Journal für Strafrecht

Juristenzeitung

Kritische Vierteljahresschrift für Gesetzgebung und Rechtswissenschaft

Kritische Justiz

Kreditwesengesetz

Law Review

Monatsschrift für Kriminologie und Strafrechtsreform

Neue Zeitschrift für Gesellschaftsrecht 
NZWiSt

OECD

OEIGWG

OWiG

p./pp.

RIW

RW

StGB

StraFo

StV

U.N.

USAM

USSG

VbVG

wistra

$\mathrm{WpHG}$

WM

ZIP

ZIS

ZRP

ZStW

ZWF

ZWH
Neue Zeitschrift für Wirtschafts-, Steuer- und Unternehmensstrafrecht

Organisation for Economic Co-operation and Development

Open-ended intergovernmental working group

Ordnungswidrigkeitengesetz

page/pages

Recht der internationalen Wirtschaft

Rechtswissenschaft

Strafgesetzbuch

Strafverteidiger-Forum

Strafverteidiger

United Nations

United States Attorney's Manual

United States Sentencing Commission Guidelines

Verbandsverantwortlichkeitsgesetz

Zeitschrift für Wirtschafts- und Steuerrecht

Wertpapierhandelsgesetz

Wertpapier-Mitteilungen

Zeitschrift für Wirtschaftsrecht

Zeitschrift für Internationale Strafrechtsdogmatik

Zeitschrift für Rechtspolitik

Zeitschrift für die gesamte Strafrechtswissenschaft

Zeitschrift für Wirtschafts- und Finanzstrafrecht

Zeitschrift für Wirtschaftsstrafrecht und Haftung im Unternehmen 


\section{Introduction}

Over the past two decades, companies have been increasingly implementing programs in order to achieve better compliance with legal and non-legal regulations and to facilitate the detection of respective infringements. ${ }^{1}$ In addition to these "compliance programs," there are also programs with broader or different aims, especially programs promoting ethical values ("business ethics"), programs for the social activities of companies ("corporate social responsibility"), programs managing corporate risk ("risk management programs"), and programs for good and transparent company structures ("corporate governance"). ${ }^{2}$ The concepts and programs often overlap or are combined in umbrella approaches, e.g., the GRC concept (Governance, Risk management, and Compliance). ${ }^{3}$

With respect to legal issues, compliance programs supporting the prevention and detection of crime are of particular interest (so-called criminal compliance). ${ }^{4}$ They not only promise to reduce crime and improve the companies' reputations. They are also gaining legal relevance, since they are required by law in specific areas, and they can eliminate or reduce the criminal liability of companies when employees infringe legal provisions (corporate crime). Compliance is therefore part of a new discussion on legal approaches in the global risk society, where private and public spheres merge more closely in order to enhance their efforts against (trans-

1 This paper was prepared for the General Conference on Section III of the XXth AIDP International Congress of Penal Law "Prevention, Investigation, and Sanctioning of Economic Crime" in Freiburg i. Br. (Germany), 18-20 June 2018. It refers to the national reports prepared for the conference from Argentina, Austria, Belgium, Brazil, Bulgaria, China, Colombia, Finland, Italy, Japan, Luxembourg, Poland, Portugal, Russia, South Korea, Spain, and Turkey that partly cover the topic compliance. In the following, the national reports that will be published separately are referred to by name only (italicized country name). This paper builds in part on the contribution by Engelhart, in: Brodowski et al. (eds.), Regulating Corporate Criminal Liability, 2014, pp. 53-76.

2 For the different concepts and overlaps, see Engelhart, Sanktionierung von Unternehmen und Compliance, pp. 40 ff.; Nieto Martín, in: Kuhlen/Kudlich/Ortiz de Urbina (eds.), Compliance und Strafrecht, 2012, p. 27 (29 f.).

3 See Keuper/Neumann, Governance, Risk Management and Compliance (2010); Steinberg, Governance, Risk Management, and Compliance (2011). See also Hodges, Law and Corporate Behaviour (2015) and Hodges/Steinholtz, Ethical business practice and regulation: a behavioural and ethical values-based approach to compliance and enforcement (2017).

${ }^{4}$ See Bock, Criminal Compliance (2011); Engelhart, Sanktionierung von Unternehmen und Compliance, p. 497 ff.; Rotsch, ZIS 2010, 614; Sieber, Festschrift Tiedemann, p. 449 (475 ff.); Tiedemann, Wirtschaftsstrafrecht, p. 5 ff. 
national) economic crime. ${ }^{5}$ This contribution concentrates mainly on criminal law and compliance but also takes into account other relevant developments. After defining compliance (II.) the relevance of compliance in legal regulations is analysed. The possible levels of (regulated) self-regulation (IV.A.1) and aspects of an umbrella compliance theory (IV.A.2.) are addressed next.

\section{Definitions}

\section{A. Compliance}

Compliance is not clearly defined within the context of (lacking) legal regulation. ${ }^{6}$ In general and in the following, compliance will be understood as the adherence to regulations. These regulations can be of a legal or of a non-legal nature, especially in cases of ethical and moral guidelines or social conventions. ${ }^{7}$ From a regulatory perspective, adherence to legal regulations is decisive, although nonlegal regulations can play a role in guaranteeing adherence to legal ones. Compliance is not restricted to a certain area of law or business but can be relevant for all legal areas and all types of business. ${ }^{8}$

Criminal compliance is the part of compliance that deals with the adherence to criminal law. Criminal law in this context is understood in a comprehensive sense, including, e.g., both the German "Kriminalstrafrecht" and its "Ordnungswidrigkeitenrecht".

\section{B. Compliance Program}

A compliance program is the sum of measures to secure adherence to (legal) regulations. ${ }^{9}$ It comprises preventive measures to thwart rule-breaking as well as detection measures to discover rule-breaking. Insofar, it is of a twofold nature, although the emphasis is very often on the preventive aspect. In this sense, compli-

5 See the contributions by Sieber, ZStW 119, p. 1 (35 et seq.); Sieber, Festschrift für Tiedemann, p. 449 (475); Sieber, Rechtstheorie 41 (2010), p. 151 (189).

6 See, e.g., Engelhart, Sanktionierung von Unternehmen und Compliance, p. 40 et seq.; Rotsch, ZStW 125 (2013), 481 (483).

7 Basically, internal rules can even contradict legal regulations [see Rotsch, ZStW 125 (2013), p. 481 (490) pointing to business considerations being first on the agenda]. Nowadays, it might be rather unlikely that there is an intentional contradiction of internal rules and legal regulations. If a corporation acts in several jurisdictions, however, different contradicting legal approaches and rules can cause great implementation problems.

8 See also Saliger, RW 2013, 263 (271).

9 Sometimes the term "compliance" is also used to describe compliance programs. In order to distinguish the objective (adherence to regulations) from the method used (a compliance program), each aspect should be dealt with separately. 
ance programs do not address the traditional distinction between prevention and repression but instead, by blurring these categories, aim at a comprehensive concept intergrating both aspects.

A compliance measure is a respective single measure, in most cases part of a much more complex and comprehensive compliance program.

The nature of compliance programs can vary greatly from topic-specific programs (anti-corruption) to sector specific ones (financial market) and even to general ones, or the program stresses certain aspects (such as ethics; hence the USSG ${ }^{10}$ feature a Compliance and Ethics Program). This causes difficulties when comparing and analyzing programs. Indeed, the elements of an effective compliance program are often disputed and pose a major challenge for legislators, companies trying to implement such a program, and public institutions taking such programs into account (be it as a regulatory body or a sanctioning body).

\section{Compliance Investigations}

Compliance investigations (also internal investigations) are investigations conducted within an organization against an alleged violation of regulations and compliance measures. They are conducted by the organization itself or on behalf of the organization. Such investigation procedures can be provided for by a compliance program and are then part of a compliance monitoring system. As such, internal investigations are not necessarily connected to compliance mechanisms; they overlap to a great extent with neighboring questions of cooperation with state authorities and the privatization of public duties (especially criminal investigations).

\section{Relevance of Compliance Programs}

\section{A. Development of the Compliance Movement}

Compliance has gained greatly in importance in theory and in practice over the last 20 years. ${ }^{11}$ It looks back on a much longer history, especially in the USA, although neither the terminology nor the concept was as comprehensive as it is to-

$10 \S 8$ B 2.1 USSG ("Effective Compliance and Ethics Program"). The guidelines are available under https://www.ussc.gov/guidelines/2016-guidelines-manual (as of 15.8.2018).

11 See Arroyo Zapatero, Compliance (2013); Bock, Criminal Compliance (2011); Engelhart, Sanktionierung von Unternehmen und Compliance (2nd edn. 2012); Görling et al. (eds.), Compliance (2010); Hauschka (ed.), Corporate Compliance (3rd edn. 2016); Moosmayer, Compliance (3rd edn. 2015). 
day, and it had not yet gained major practical importance. ${ }^{12}$ But from the discussion in the 1930s about corporate controls in companies not being run by their owners to cartel controls in the second half of the 20th century and even to business ethics in the 1970s and 1980s, the idea of fostering a legal environment within companies has been addressed from various sides. Also, the setting of standards such as DIN, EN, and ISO by private organizations has been a long-standing method of selfregulation with recognition by the state, e.g., relevant standards for determining duties of care. ${ }^{13}$ An early example of regulated self-regulation is the German discussion on internal sanctions (so-called "Betriebsjustiz") in the 1960s and 1970s. ${ }^{14}$ They were meant to complement criminal prosecutions in cases of minor crimes ${ }^{15}$ and led to a comprehensive system of non-criminal sanctions in labor law. ${ }^{16}$ Insofar, links between private "regulation" and legal norms have a long tradition.

The home country of compliance is the United States of America, where compliance has become an integral part of business life and the work of state authorities. The starting point for its worldwide success can be pinpointed as the introduction of the Federal Corporate Sentencing Guidelines in 1991, which foster the concept of being a good corporate citizen in the context of corporate criminal liability and provide incentives for being compliant. ${ }^{17}$ This approach was taken up by the Italian legislator in 2001, at a still early stage of discussion outside the USA. ${ }^{18}$ Soon, the debate became livelier. ${ }^{19}$

12 See Engelhart, Sanktionierung von Unternehmen und Compliance, p. 285 ff.; Pitt/Groskaufmanis, 78 Geo. L. J. 1559 (1989-90), 1575 ff.; Walsh/Pyrich, 47 Rutgers L. Rev. 605 (1994-95) 649 ff. For the development of economic criminal law, see Achenbach, Festschrift für Tiedemann, p. 47; Engelhart, 15 German Law Journal (2014), p. 693 (espec. 698 f.).

13 See Bosch, Organisationsverschulden, p. 411 ff.; Rönnau, in: Professorinnen und Professoren der Bucerius Law School (eds.), Begegnungen im Recht, 2011, p. 237 (239).

14 See Herschel, Betriebsbußen, 1967; Bovermann, Die „Betriebsjustiz“ in der Praxis, 1969; von Lentzke, Betriebsjustiz, 1972; Kaiser/Metzger-Pregizer (eds.), Betriebsjustiz, 1976; Jentsch, Betriebsjustiz, 2005; see also the proposal for a bill by Arzt et al. (ed.), Entwurf eines Gesetzes zur Regelung der Betriebsjustiz, 1975. The idea of sanctions within companies is much older, see, e.g., the German regulation in $\S 134 \mathrm{~b} \mathrm{GewO}$, which was in force until 1st May 1934 and provided that internal sanctions had to have a written basis in work rules ("Arbeitsordnung"). It also provided that the nature and amount of the sanction, the manner in which they are fixed and, if monetary, their confiscation and the purpose for which they are to be used must be stated.

15 See Kuhlen, in: Kuhlen/Kudlich/Ortiz de Urbina, Compliance und Strafrecht, p. 1 (20 f.) and Jentzsch, Betriebsjustiz, pp. $36 \mathrm{ff}$.

16 See Kuhlen, in: Kuhlen/Kudlich/Ortiz de Urbina, Compliance und Strafrecht, p. 1 (21); for an overview of possible sanctions, see Sieber/Engelhart, Compliance Programs, p. 82.

17 Beale, ZStW 126 (2014), 27; Gruner, Corporate criminal liability and prevention (2004-2018); Laufer, Corporate bodies and guilty minds (2006); Nanda, in: Pieth/Ivory (eds.), Corporate criminal liability, p. 63. See also Engelhart, Sanktionierung von Unternehmen und Compliance, pp. 121 ff.; Perschke, Festschrift für Achenbach, p. 317.

18 Castaldo, wistra 2006, 361; Javers, in: Sieber/Cornils (eds.), Nationales Strafrecht in rechtsvergleichender Darstellung, p. 408; Kuhlmann, Verbandssanktionierung in Italien, 2014; Maglie, in: Pieth/Ivory (eds.), Corporate criminal liability, p. 255; Nisco, GA 2010, 525; Rübenstahl, RIW 2012, 505. 
The Siemens corruption case had a great impact on the development when it became public in 2006. ${ }^{20}$ Although Siemens claimed to have one of the leading compliance systems in the world, it did not prevent several serious cases of corruption. American and German authorities investigated the incidents, extensive internal investigations were carried out, and the company was heavily sentenced. But the authorities also acknowledged Siemens' substantial cooperation and its improvement $^{21}$ of the compliance system, thus avoiding much higher sanctions. In Germany and other countries, this case not only triggered a shift in corporate attitude towards the need to be compliant ${ }^{22}$ but also showed legislators the power of using the corporate criminal liability mechanism to stimulate cooperation and criminal compliance on the corporate side.

Since then, compliance has become a major topic in many countries in Europe, increasingly in Asia (see $\operatorname{Japan}^{23}$ ), and in Latin-America (see Brazill ${ }^{24}$ ), too. ${ }^{25}$ In many cases, it is first addressed by the business community (e.g., banks, financial institutions, and other companies with contacts to or that do business in countries with a more developed compliance structure) and then by regulators and legislators providing a compliance-oriented legal framework. The discussion and regulations are often based on or greatly influenced by the American approach. Hence, compliance is usually discussed in connection with corporate criminal liability.

Yet, the current discussion has become much more detailed and specific. Questions relating to corporate specialists ( such as compliance officers ${ }^{26}$ ), compliance and

19 See, e.g., early discussions by Bussmann, MschrKrim 2003, pp. 89 ff. (concentrating on business ethics) or by Hefendehl, 8 Buffalo Law Review (2004), pp. $51 \mathrm{ff}$. and $\mathrm{He}$ fendehl, JZ 2006, pp. $119 \mathrm{ff}$.

20 See for the case and the following facts mentioned in: Arzt, Festschrift für Stöckel, 2010, p. 15; Engelhart, Sanktionierung von Unternehmen und Compliance, pp. 2-9; Jahn, $\mathrm{StV} 2009,41$. On the aspect of internal investigations in this case, see Rödiger, Strafverfolgung von Unternehmen, Internal Investigations und strafrechtliche Verwertbarkeit von "Mitarbeitergeständnissen" (2012); Wewerka, Internal Investigations (2012).

21 See Moosmayer/Sölle/Toifl, in: Petsche/Mair (eds.), Handbuch Compliance, pp. 403 ff.

22 See, e.g., for the development of the discourse in Germany, Sieber/Engelhart, Compliance Programs, p. 21 ff.; Bock, in: Rotsch (ed.), Compliance Diskussion, p. 63; Rotsch, Festschrift für Samson, p. 141. For the Spanish and US-American development and discussion on compliance, see Nieto Martín, in: Festschrift Tiedemann, p. 485; on the Spanish discussion, see also Bacigalupo, in: Rotsch (ed.), Compliance-Diskussion, p. 135; Bacigalupo, Compliance y derecho penal (2011); Carbonell Mateu, ZStW 123 (2011), S. 331; Ortiz de Urbina, in: Kuhlen et al. (eds.), Compliance und Strafrecht, p. 227. For the Anglo-American influence, see also Huck (ed.), Compliance (2013).

23 Japan.

24 Brazil.

25 In other countries, the discussion is at the beginning, e.g., Russia.

26 See on the responsibility of compliance officers e.g. the German decision in BGHSt 54, 44. See for details Fateh-Moghadam, in: Steinberg/Valerius/Popp (eds.), Das Wirtschaftsstrafrecht des StGB, pp. $25 \mathrm{ff}$. 
the duty of due supervision, compliance within groups of companies, compliance and data protection, and corruption compliance as well as the scope and limits of compliance investigations and procedural aspects are dealt with separately. Also, the discussion and the regulative approach is by far not limited to criminal law questions but include, or even predominantly concentrate on, liability under corporate and administrative law. Insofar, compliance is seen as a comprehensive regulative approach, where criminal law is (only) one important layer. ${ }^{27}$ From the perspective of the companies, implementing compliance programs is very much motivated by the wish to protect the entity, senior management, and its shareholders. ${ }^{28}$

\section{B. Legal Situation}

Compliance and the law is a relationship that is not easy to cover as there are many facets involving a great variety of approaches. ${ }^{29}$ Companies can set up compliance programs in any business and legal field with almost any measures they like. This freedom of self-regulation as part of doing business is often constitutionally guaranteed and becomes a system of regulated self-regulation when the state provides a legal framework for the way compliance is dealt with by companies. Legal regulations can call for or foster compliance as such, the coverage of certain areas, or the taking up of certain measures. Three different levels are distinguishable in existing legislation where compliance can become relevant. Compliance can influence corporate and individual responsibility, can be a factor in determining a sanction when regulations have been breached, and it can also be a decisive factor in proceedings (mostly in a sanctioning procedure).

The legal areas in which corporate compliance programs are relevant under national law vary greatly among the countries. They can be relevant for all business areas,${ }^{30}$ for the financial sector, ${ }^{31}$ for a certain list of crimes, ${ }^{32}$ or merely for several major crimes such as corruption, money laundering, and terrorism. ${ }^{33}$ Often, compliance requirements in high-risk sectors, such as the financial market or in regard to serious crimes like terrorism, are much higher and much more detailled than in other areas of law. From the point of view of companies, the legal situation is only partially reflected, as compliance programs concentrate on legal issues mainly in

${ }^{27}$ For the theoretical approach, see also infra IV.B.

28 See Brazil. See also Saliger, RW 2013, 263 (275).

29 See IV.A below for the various regulative strategies.

30 See Austria, Brazil. The same applies, e.g., to the USA and Germany; see Engelhart, Sanktionierung von Unternehmen und Compliance, pp. 147 f., 397 ff.

31 See Luxembourg.

32 See Italy.

33 See Bulgaria, Russia. 
areas where reputational risks and risks of (criminal) prosecution are high such as corruption and anti-trust offenses or data protection issues. ${ }^{34}$

\section{Responsibility}

In order for compliance to be a relevant criterion for establishing corporate or individual liablity, a legal provision is needed that allows compliance to be taken into account. This is self-evident in cases where setting up and implementing a compliance program is directly required by law. It is much more difficult in cases where the regulation uses the term compliance but means concepts that embrace compliance programs.

\section{a) Direct Compliance Obligations}

Regulations clearly requiring compliance programs are rather limited and often only sector-specific. An example is the German $\S 25$ a para. 1 (3) Nr. 3c KWG requiring financial market companies to have a "compliance function" as part of their internal control system. ${ }^{35}$ Similarly, the Luxembourg Financial Sector Act (FSA) in Art. 5 (1a) requires credit institutions and investment firms to have "robust internal governance arrangements" as specified by several circulars ${ }^{36}$ comprising a "compliance function" with the aim of anticipating, identifying, and assessing compliance risks. In these cases, compliance is part of a wider concept of risk management. Having an effective compliance program fulfills the legal requirements and avoids further actions by excluding responsibility for non-implementation (e.g., by means of administrative action, civil liability, or criminal liablity).

\section{b) Indirect Compliance Obligations in Corporate/Civil Law}

Regulations that require a certain generalised standard of care are far more frequent than the explicit requirement to implement compliance measures. A major area for such an approach is company law. For example, the Japanese Companies Act provides that the board of directors should develop "systems necessary to ensure that the execution of duties by directors complies with laws and regulations." 37

34 See, e.g., the results of the study by Sieber/Engelhart, Compliance Programs, pp. 39-52.

35 See $\S 25$ a para. 1 sentence 3 No. 3c KWG.

36 See sec. 6.2.6. "Compliance function" of the Circular CSSF [Commission de Surveillance du Secteur Financier] 12/552 as amended by Circulars CSSF 13/563 and CSSF 14/597 concerning "Central administration, internal governance and risk management"; see also Circular 04/155 concerning "The Compliance function". For details, see the report on Luxembourg.

37 See the report on Japan with reference to Art. 362 (4) (vi) of the Companies Act. 
Here, the requirement is closely connected to corporate governance and transparent and effective corporate structures.

Another area in corporate law involves the general obligation of the executive management to operate and supervise the organization and business conducted. This obligation includes the general responsibility to assure that the corporation functions within the bounds of law to achieve its purposes. Executives have farreaching discretion in this regard, which is supported, for example, by the business judgement rule: ${ }^{38}$ As long as they act with due diligence, no liability arises from their actions. Due diligence requires that a corporate information and reporting system such as that provided for by compliance programs has been implemented. ${ }^{39}$

How the compliance discussion shaped legal interpretation can be seen in German corporate law. The German Stock Corporation Act (Aktiengesetz) provides for a duty of the manangement board "to ensure that developments threatening the continuation of the company are detected early" ( $\$ 91$ (2) AktG) and that "the members of the management board shall employ the care of a diligent and conscientious manager" ( $\$ 92$ (1) $1 \mathrm{AktG}$ ). These duties have traditionally been interpreted to include mechanisms to avert serious risks from the company by taking necessary organizational precautions. ${ }^{40}$ For about ten years now, the rules have been interpreted to include a compliance responsibility, with much more specific criteria for fulfilling the very general corporate obligations. ${ }^{41}$ Although many details are disputed, ${ }^{42}$ one thing remains clear: An effective compliance program is suitable to fulfill corporate standards and exclude liability for breach of these obligations. This is a decisive incentive for the management board to take up compliance measures.

\section{c) Indirect Compliance Obligations in the Law of Public Sanctions}

Like corporate law and questions of civil liablity, compliance is relevant for the law of public sanctions. In regard to civil liability, the separation between duty and defense (is having the compliance program part of the duty itself, or is having a compliance program merely a defense against alleged wrongdoing?) is often not

38 This principle is derived from common law and assumes that executives are being motivated in their behavior by a bona fide regard for the interests of the company; see in the USA, e.g., Aronson v. Lewis, 473 A.2d 805 (Del. 1984).

39 See, e.g., the leading U.S. case In Re Caremark International Inc. Derivative Litigation, 698 A.2d 959 (Del. Ch. 1996). See also Brown, 26 Del. J. Corp. L. 1 (2001); Joseph, 35 Am. Crim. L. Rev. 1017 (1997-98); and the report for Brazil.

40 See Engelhart, Sanktionierung von Unternehmen und Compliance, pp. 499-501, 772-773.

41 See Fleischer, in: Spindler/Stilz, Aktiengesetz, 3rd edn. 2015, § 91 para. 47 ff.; Spindler, in: Münchener Kommentar zum Aktiengesetz, 4th edn. 2014, § 91 para. $52 \mathrm{ff}$.

42 For example, it is questionable to what extent smaller companies are affected and what the compliance measures should look like; see Spindler, in: Münchener Kommentar zum Aktiengesetz, 4th edn. 2014, § 91 para. 63 ff. 
strictly made, although it may be relevant for the burden of proof, etc. For sanctioning systems, especially criminal law, the strict separation of the elements of the offense (and a clear concept of duties to fulfill) and grounds for justification are more important: ${ }^{43}$ The elements of the offense (in German: the "Tatbestand") express the expected behavior, whereas grounds for justification describe general or personal circumstances not to follow the general rule in exceptional cases. This question is relevant for the construction of corporate criminal liability systems. It has, e.g., major consequences in common law jurisdictions as to who has to provide evidence (since the accused has the burden of providing evidence for grounds of justification but not for fulfilling the elements of crime).

In many cases, compliance programs can be relevant for shaping the necessary duties and insofar contribute to determining the elements of crime. An example is the 2008 German Siemens/Enel case, one of several criminal and civil proceedings that followed the corruption investigations; based on the Siemens compliance rules that forbade the creation of black accounts, the court concluded that having such accounts is a criminal breach of trust. ${ }^{44}$ The case shows that compliance rules do not necessarily reduce liability but may also "trigger" liablity in areas with unclear duties.

Another example is the German administrative offense (Ordnungswidrigkeit) of the breach of duty of supervision according to $\S 130 \mathrm{OWiG}$. It not only allows the individual sanctioning of high-ranking corporate officials but is also a common basis for corporate liability under $\S 30 \mathrm{OWiG}$, e.g., as applied in the Siemens case. ${ }^{45}$ This offense holds the owner of an organization liable when the lack of due supervision results in the commission of a criminal or administrative offense by an employee. Like in corporate law, the interpretation of this general duty has very much concentrated on compliance requirements in recent years. ${ }^{46}$ Although the regulation does not constitute an overall duty to set up a compliance program, having an effective program fulfills this duty and hence is a major incentive for companies to invest in one.

In addition to these general obligations, duties for specific areas often exist. One example is the Portuguese regime for the prevention and repression of money laundering. ${ }^{47}$ Entities have a new "duty of control" that, in essence, establishes a corpo-

43 See Nieto Martín, in: Kuhlen/Kudlich/Ortiz de Urbina (eds.), Compliance und Strafrecht, p. 27 (36 ff.)

44 The court applied $\S 266$ StGB (Embezzlement and abuse of trust); see BGHSt 52, 323.

45 See Engelhart, in: Fiorella/Stile (eds.), Corporate criminal liability and compliance programs, pp. 167 (184 ff.).

46 See Engelhart, in: Esser/Rübenstahl/Saliger/Tsambikakis (eds.), Wirtschaftsstrafrecht, $\S 130 \mathrm{OWiG}$ para. $39 \mathrm{ff}$. and, for the development, Engelhart, Sanktionierung von Unternehmen und Compliance, pp. $773 \mathrm{f}$.

47 See Portugal. 
rate obligation to design, implement, and monitor the execution of a suitable and tailor-made compliance program.

Besides such specific offenses with special duties, compliance programs can shape general duties in criminal law, for example in regard to the standards for negligence or duties to act in omission cases. ${ }^{48}$ Written documentation of detailed responsibilities, duties, or measures to be taken can especially help determine whether the necessary standard of care was reached or an obligation to act had existed and been fulfilled. Insofar, compliance helps clarify previous "grey zones," like the specific duties in the aforementioned Siemens case involving breach of trust. This can be helpful for the accused if he followed the rules, but it can also be a disadvantage because there are no longer any doubtful areas, making a ruling "in dubio pro reo" much more unlikely.

\section{d) Indirect Compliance Obligations in Corporate Criminal Liability Laws}

Compliance can also be highly relevant for corporate criminal liability. This is especially the case when corporate liability is not solely based on the commission of an offense by an employee. ${ }^{49}$ It is the case, for example, in Italy, Austria, Switzerland, and the United Kingdom. ${ }^{50}$

In Italy, Legislative Decree No. 231 of 8 June $2001,{ }^{51}$ introduced a quasi-criminal responsibility (administrative in name, but criminal in nature) for legal persons. ${ }^{52}$ This legislation directly took up the idea of compliance programs. Corporate liability is based on two different forms: If a senior manager commits a crime, the company is assumed guilty unless it can prove (inversion of the burden of proof) the extraneousness of the crime by demonstrating that it had an effective (compliance) program in place to prevent crimes and that the program had also been controlled effectively. For offenses of subordinate employees, the company is liable if the offense was due to the lack of supervision and control of senior managers, but only if the company has no effective (compliance) program.

The idea of basing corporate criminal liability on the lack of due supervision or control was taken up by the legislator in Austria, building on European develop-

48 For details, see Engelhart, Sanktionierung von Unternehmen und Compliance, pp. 404 ff.; Sieber, Festschrift für Tiedemann, p. 449 (470 ff.).

49 For the possible models of corporate criminal liability, see Engelhart, Sanktionierung von Unternehmen und Compliance, pp. $361 \mathrm{ff}$.

${ }^{50}$ For the examples, see Engelhart, in: Brodowski et al. (eds.), Regulating Corporate Criminal Liability, 2014, pp. 53 (62 ff.).

51 D.Lgs. 8 guigno 200, n. 231.

52 See Castaldo, wistra 2006, 361; Javers, in: Sieber/Cornils, Nationales Strafrecht in rechtsvergleichender Darstellung, vol. 4, p. 408; Kuhlmann, Verbandssanktionierung in Italien (2014); Maglie, in: Pieth/Ivory (eds.), Corporate criminal liability, p. 255; Nisco, GA 2010, 525; Rübenstahl, RIW 2012, 505. 
ments. ${ }^{53}$ In 2005, Austria introduced the Corporate Liability Act. ${ }^{54}$ Inter alia, ${ }^{55}$ a company is liable for the offense of a staff member that was facilitated by a decision-maker neglecting the necessary diligence in supervising that staff member. Although the act does not specify which measures are necessary in order to exercise "due supervision," compliance measures are relevant for proving the due standard of care. ${ }^{56}$

In 2003, Switzerland introduced a system of corporate criminal liability, ${ }^{57}$ which puts more emphasis on the organizational structure than merely on the aspect of supervision. The company is responsible for the lack of due organization if this deficiency makes it impossible (for the state) to hold an individual responsible. Additionally, the company is responsible for the commission of certain offenses by employees if the company has not taken all necessary and reasonable organizational measures to prevent such offenses.

The Corporate Manslaughter and Corporate Homicide Act 2007, which applies to the United Kingdom in its entirety, takes the idea of compliance even one step further. ${ }^{58} \mathrm{~A}$ company is liable if the way in which it manages or organizes its activities both causes a death and amounts to a gross breach of a relevant duty of care owed to the deceased by the company. Senior management must have played a substantial role in the gross breach. Yet, corporate liability in this case is not dependent on the commission of an offense by a person within the company. Liability merely requires the company to fall below a required standard of due organization and supervision (for which senior management is responsible) that leads to the death of a person.

These examples show how compliance programs can be directly relevant when determining the elements of crime. In a similar way, they can be relevant as a ground for defense against corporate criminal liability. One example is South Korea, where a "due diligence" defense is possible in competition law and for finan-

${ }^{53}$ For the European approach to corporate criminal liability, see Engelhart, eucrim 2012, $110 \mathrm{ff}$.

${ }^{54}$ Bundesgesetz über die Verantwortlichkeit von Verbänden für Straftaten (Verbandsverantwortlichkeitsgesetz - VbVG), BGB1. I Nr. 151/2005, Revision: BGB1. I Nr. 112/2007; on the constitutionality of the law, see Engelhart, ZWH 2018, 165.

55 A company is also liable if a decision-maker commits an offense for the benefit of the company; see $\$ 3$ (2) VbVG.

56 See Staffler, JSt 2016, p. 500 (502 f.); see also Lewisch (ed.), Zauberwort Compliance? 2012, and Dannecker/Leitner (eds.), Handbuch der Geldwäsche-Compliance (2010) for details.

57 Art. 102 Swiss Criminal Code; for details, see Forster, Verantwortlichkeit des Unternehmens (2006); Geiger, Organisationsmängel (2006); Perrin, in: Pieth/Ivory (eds) Corporate Criminal Liability, p. 193 (197). In regard to corporate compliance, see, e.g., Mueller, Compliance-Management (2007); Roth, Compliance (2011).

58 See Almond, Corporate Manslaughter (2013); Matthews, Blackstone's Guide to the Corporate Manslaughter (2008); Pinto/Evans, Corporate Criminal Liability (2013). 
cial market offenses. ${ }^{59}$ Portugal is discussing whether a compliance program constitutes a ground for justification under Art. 11 (6) Criminal Code when "criminal liability of the corporation is excluded whenever the individual perpetrator acted against express orders or instructions properly issued. ${ }^{\prime 60}$

\section{Sanctions}

Within sanctions, compliance has mainly two functions: First, it can be a (decisive) mitigating or aggravating factor when determining a sanction. Second, the obligation to implement a compliance program can serve as a sanction on its own.

Compliance as a mitigating or aggravating factor in sentencing applies to individuals as well as to corporate entities. The more an individual followed (reasonable) compliance guidance and adhered to corporate standards, the more this behavior can be seen as a mitigating circumstance and less individual guilt. Vice versa, the more an individual disregarded compliance standards, the higher his individual guilt. When sentencing a corporation, a high degree of individual guilt usually means less corporate guilt. Vice versa, the more the corporate standards, procedures, or corporate climate of accepting illegality contributed to lawbreaking, the higher the corporate guilt.

An example of how compliance is integrated into sentencing rules is provided by the United States Corporate Federal Sentencing Guidelines (USSG), regulated as chapter 8 of the Federal Sentencing Guidelines. These rules fully implement a compliance approach for corporations at the sentencing stage. ${ }^{61}$ Compliance is relevant for the determination of a fine. An effective compliance program being implemented at the time of the commission of an offense by an employee is a mitigating factor for the corporation. $^{62}$ Vice versa, the lack of an effective compliance program in cases where precautions should have been taken can be an aggravating factor. ${ }^{63}$

Likewise, compliance programs are of importance in determining corporate guilt for corporate sanctions in Japan, especially under the Antimonopoly Act, ${ }^{64}$ or in

59 See South Korea.

60 See Portugal.

61 The current guidelines (effective 1 November 2016) are available online: https:// www.ussc.gov/guidelines/2016-guidelines-manual (as of 15.8.2018). For details on the system, see Engelhart, Sanktionierung von Unternehmen und Compliance, pp. 149 ff.; Gruner, Corporate criminal liability and prevention, $\S \S 8-11$; Kaplan/Murphy, Compliance Programs, $\S \S 3,4$; see also Laufer, Corporate bodies and guilty minds, pp. $99 \mathrm{ff}$.

$62 \S 8$ C 2.5 (f) USSG: The program reduces the so-called culpability score, which determines the minimum and maximum multiplier necessary to calculate the fine range.

$63 \S 8 \mathrm{C} 2.8$ (a) (11) USSG: The lack of a compliance program is a circumstance that should be considered by the court when determining the fine within the calculated fine range.

64 See Japan. 
corruption cases in Colombia. ${ }^{65}$ In Spain, Art. 31-bis (2) Código Penal provides for exclusion of the sentence in case of an effective compliance program; if the program is only partly effective, mitigation of the sentence is possible. ${ }^{66}$

Apart from compliance programs in force at the time of the wrongdoing, compliance programs set up after the incident or substantial improvements of existing ones can also be taken into account when sentencing. ${ }^{67}$ Especially together with other activity after the act (such as providing remedies), such effort indicates a positive attitude towards being law abiding in the future (and is hence worth mitigating the sentence). In this case, the preventive aspect of avoiding future incidents takes precedence over the repressive function of evaluating merely past behavior at the time of the wrongdoing.

Since criminal sanctions for companies are traditionally monetary, the compliance movement has triggered new corporate sentences. For example, the USSG provide for a specific compliance sentence, as the court can order the company to improve or set up a comprehensive compliance program. ${ }^{68}$ Such a sentence imposing the restructuring of a company can be more severe than any financial penalty payment, as it can substantially change the internal structure of a company. The company therefore has to improve the corporate structures that contributed to the offense of an employee. For similar sanctions without a trial, see infra III.B.3.

Integrating compliance at the sentencing stage is one of the most important approaches. For example, it influenced the German draft law on corporate criminal liability presented in November 2013 by the state of North Rhine-Westphalia in which compliance is a key element of the proposal: ${ }^{69}$ If compliance measures were

65 Art. 7 of Law 1778 (the 2016 law on transnational corruption) provides that the existence and implementation of compliance programs plays a role when determining administrative fines in international corruption cases. Similarly, in domestic corruption cases, the existence, implementation, and effectiveness of a compliance and ethics program shall be taken into account in corporate sentencing (see Art. 34 of Law 1474 - the Anti-Corruption Statute enacted in 2011 - that was modified by Law 1778 in 2016).

66 The rules were mainly introduced in 2010, with a major reform in 2015; see Jaén Vallejo/Perrino Peréz, La reforma penal de 2015, pp. 50 ff.; for a systematic understanding of the rules (that are partly seen as excluding corporate guilt), see Gómez-Jara Díez, in: Bajo Fernández/Feijoo Sánchez/Gómez-Jara Díez (eds.), Tratado de responsibilidad penal de las personas jurídicas, p. 143 (177 ff.); for the historic development, see Carbonell Mateu, ZStW 2011, pp. 331 ff.; see also Staffler, ZWF 2017, p. 241; Tauschwitz/Tornero, CCZ 2016, 18.

67 This was, e.g., especially mentioned in the German proposal "Entwurf eines Gesetzes zur Einführung der strafrechtlichen Verantwortlichkeit von Unternehmen" (infra Fn. 69), p. 54. See also $\$ 5$ (3) No. 5 VbVG in Austria.

$68 \S 8$ D 1.4 (b) (1) USSG.

69 Entwurf eines Gesetzes zur Einführung der strafrechtlichen Verantwortlichkeit von Unternehmen. See Kutschaty, ZRP 2013, 74 (responsible for the proposal in his function as the minister of justice of North Rhine-Westphalia). See also Hoven, ZIS 2014, 19; Mitsch, 
in place at the time of the commission of an offense by an employee, this is regarded as being a relevant sentencing factor for the corporate sentence. If the company took up compliance measures to prevent future incidents after the incident occurred, the court can desist from imposing a sentence. Ultimately, the proposal provides for a kind of compliance sentence, as the court can order the implementation of a compliance program as a condition of probation.

Cooperation with state authorities is closely connected with compliance but not necessarily an integral feature of compliance programs. Cooperation is often considered a substantial mitigating factor. Particularly leniency systems in antitrust law, e.g. in South Korea, ${ }^{70}$ provide for an attractive reduction of a fine, etc. if corporate misconduct is disclosed to the authorities and internal investigations to clarify the incidents are conducted. ${ }^{71}$

\section{Proceedings}

Compliance can play a major role in proceedings aiming to sanction lawbreaking, especially in criminal cases, either when deciding to initiate proceedings or to terminate them with a deal.

When deciding to launch official proceedings or whether to file a charge and submit it to a court, the development and implementation of an effective compliance program can be considered a circumstance favorable to the corporation concerned, as is the case in Japan ${ }^{72}$ and the USA. ${ }^{73}$ This is especially the case when the corporate environment hardly contributed to the crime, as the guilt of the individual predominates. Vice versa, if the corporate environment and a weak compliance program contributed substantially to the crime, this can be a decisive criterion for not prosecuting the individual.

Additionally, in many national systems, criminal proceedings no longer end with a judgment after a public trial. Instead, prosecutors and courts use procedural measures to end the proceedings speedily, especially by reaching a deal with the

NZWiSt 2014, 1; Rübenstahl/Tsambikakis, ZWH 2014, 8; Schünemann, ZIS 2014, 1; Wessing, ZWH 2013, 301.

70 See South Korea.

71 See also infra III.B.3. and III.D.

72 See the report for Japan and especially Morikazu Taguchi, 'Criminal Proceedings of Corporate Crime', in: Morikazu Taguchi/Katsunori Kai/Takeyoshi Shiraishi (eds.), Corporate Crime and Compliance Programs, 2007, pp. 269. See also Katsunori, in: Baum (ed.), Deutschland und Japan: Zwei Ökonomien im rechtlichen Dialog. Zeitschrift für japanisches Recht, Sonderheft Nr. 6 (2012), pp. 85 ff.

73 See the United States Attorneys' Manual (USAM) in $\S 9-28.500$ : “it may not be appropriate to impose liability upon a corporation, particularly one with a robust compliance program in place, under a strict respondeat superior theory for the single isolated act of a rogue employee". 
accused. For example, a deal - either as non-prosecution agreement (NPA) or as deferred prosecution agreement (DPA) - is commonplace in the USA, not only when an individual is accused but also when the accused is a company. ${ }^{74}$ As a rule, such a deal not only requires the individual or company to "confess" certain offenses but also to accept "sanctions" comparable to those that are reserved for court judgments. In order to decide whether deal is a possible and especially what type of "sanction" should be part of the deal, compliance programs and the distribution of individual/corporate guilt are relevant. In the USA, deals concerning corporate crime in many cases not only include a monetary payment but also an obligation for the corporation to reform or install a compliance program. ${ }^{75}$

A similar approach is being discussed in Portugal, namely whether, at the end of the investigation phase, the prosecutor may strike a deal with the defendant to suspend the criminal proceedings for a period of time and agree on an injunctions. ${ }^{76}$ One possible injunction de lega lata is a payment to a social insitution. But legal scholars also promote the possibility of imposing an injunction to design and implement a compliance program de lege ferenda as well as the possiblity to suspend the payment of a fine after a conviction if a compliance program is implemented. ${ }^{77}$

Whereas such "informal sanctions" offer the prosecution great flexibility and are often welcomed by companies because they speed up proceedings and avoid a public trial, the development is not without major risks to legal certainty and the balance of powers between the executive and the judiciary. There are neither clear rules for the deal, ${ }^{78}$ nor is the case investigated as regards death or doubtful facts or legal questions clarified, nor is there a real control mechanism.

In addition, strong emphasis on cooperation and pressure to conduct internal investigations after an incident can be counterproductive for the promotion of compliance efforts. Putting cooperation first on the prosecutorial agenda fosters a climate in which a company does nothing or only the very minimum until an incident is addressed by the authorities; but then, it puts all its efforts into a kind of "super-

74 See the high number of guilty pleas in federal court proceedings that are regularly based on a deal and that reached an all-time high at 96 percent in 2010 (United States Sentencing Commission, 2010 Sourcebook of Federal Sentencing Statistics, table 53); in 2017, the figure was at 92 percent (United States Sentencing Commission, 2017 Sourcebook of Federal Sentencing Statistics, table 53). See also Engelhart, Sanktionierung von Unternehmen und Compliance, pp. 276, 746.

75 See Markoff, 15 University of Pennsylvania Journal of Business Law 797 (2012-2013); McConnell/Martin/Simon, 33 Houston Journal of International Law 509 (2010-2011); Ramirez, 93 Marquette Law Review, 971 (2009-2010) as well as Engelhart, Sanktionierung von Unternehmen und Compliance, pp. $739 \mathrm{ff}$.

76 See Portugal.

77 See Portugal.

78 For instance, there are only a few basic guidelines for prosecution in the USA in the United States Attorneys' Manual (USAM), Title 9, Chapter 28. 
cooperation." Such short-term measures offer no real incentives for the creation of a good, long-term legal climate and structure within a company.

\section{Compliance Program}

Compliance is more or less all about effective compliance measures. Only effective compliance measures are accepted as being the right standard for excluding responsibility, mitigating sanctions, or striking a deal. The assessment of what the gold standard for compliance is is very difficult. ${ }^{79}$ One reason for this is that there is still surprisingly little sound research on what measures are really effective. ${ }^{80}$ The existing empirical evidence indicates that a comprehensive and systematic compliance program with effects on the corporate climate is the only effective tool to prevent and detect legal infringements within companies. ${ }^{81}$ Of course, different concepts, different names, and the vast array of corporate behaviour make studies and comparisons difficult. This is an old but not unsolvable problem for criminological research into economic crime.

Apart from this problem, it is rather unclear up to now what the empirical questions and what the normative questions are: Only to a certain extent is it possible to empirically determine what measures can effectively reduce infringements of rules in companies (especially economic crime). But beyond such findings, a compliance program is also a normative construction based on a certain regulatory concept and certain expectations and predictions. This aspect is often underdeveloped or missing when compliance requirements are set up by regulators or determined by state authorities, as a comprehensive compliance theory is either not reflected or non-existent.

De lege lata, this results in regulators either not providing criteria on how to construct an efficient compliance program at all or concentrating on criteria for a general framework. The USSG are an example for such a framework approach. ${ }^{82}$ Only in specific sectors, like financial market regulation, have more detailed requirements been set up.

79 On the question of how to construct compliance programs, see, e.g., Engelhart, Sanktionierung von Unternehmen und Compliance, p. 163 et seq. and 711 et seq.; Inderst, in: Inderst et al. (eds.), Compliance, 2017, p. 101; Moosmayer, Compliance, p. 31; Pieth, Anti-Korruptions-Compliance, p. 63. See also Staffler, JSt 2017, p. 320 ff.

${ }^{80}$ For an overview, see Kölbel, ZStW 125 (2013), p. 499 (513 ff.) and Kölbel, MschKrim 91 (2008), p. 22 et seq.; Krause, StraFO 2011, p. 437 (439). For studies undertaken, for example in regard to Germany, see Sieber/Engelhart, Compliance Programs (2014); Steßl, Effektives Compliance Management (2012); Ziegleder, Wirtschaftskriminalität (2010).

81 See, for more details, Engelhart, Sanktionierung von Unternehmen und Compliance, pp. 515 ff., 768 ff.; Kölbel, MschKrim 91 (2008), pp. 22 ff.; Krause, StraFO 2011, p. 437 (439); Pape, Corporate Compliance (2011), p. 154 ff.; Theile, ZIS 2008, p. 406.

82 See $\S 8$ B 2.1 USSG. For the core elements of a program, see also Japan. 
In all cases, companies end up being responsible for evaluating whether the program is effective. In most cases, state authorities do not determine the effectiveness of a program until they investigate a certain incident and then also evaluate the program. If state authorities address the compliance issue, this is done mainly by giving general guidance or by substantiating legal criteria ${ }^{83}$ and not by giving individual advice. This approach, of course, affords the companies much flexibility to adjust a program to their business, risks, and size and, in this way, is an expression of self-regulation.

The risk of ineffectively constructing the program, however, rests completely with the companies. In order to address the problem of finding an effective compliance program, several mechanism can be referred to. Among them are sample compliance programs by authorities, the setting up of standards by industry associations $^{84}$ or external review organizations like auditors, ${ }^{85}$ and technical control boards ${ }^{86}$ or international standard organizations. ${ }^{87}$ In particular, external reviews and controls, also including a formalized procedure with the possibility of getting "certified," provide additional evaluation and input (the expectation being that the involvement of such "gatekeepers" improves effectiveness).

In essence, core elements of compliance programs include a risk assessment, clarifying the rules, standards, and values (in a written document), setting up a compliance structure and process routines, education on compliance issues, a supervision and control structure, and criteria for infringements and sanctions as well as for a permanent assessment and improvement of the program ("lessons learned"). ${ }^{88}$ Insofar, an ideal

83 For example, the Federal Financial Supervisory Authority (Bundesanstalt für Finanzdienstleistungsaufsicht - BaFin) issued guidelines in 2010 (updated in 2017, see the letter from BaFin of 8.3.2017 - WA 31-Wp 2002-2009/0010, www.bafin.de), which give detailed advice on how to implement this legal framework and how to design a compliance program, Birnbaum/Kütemeier, WM 2011, p. 293; Engelhart, ZIP 2010, p. 1832; Lösler, WM 2010, p. 1917.

84 See, e.g., Bundesverband deutscher Banken, Best-Practice-Leitlinien für WertpapierCompliance (June 2011), https://bankenverband.de/media/files/BdB-Leitlinien_WertpapierCompliance_062011.pdf (as of 15.8.2018).

85 See, e.g., the auditing standard for compliance programs issued by the German Institute of Public Auditors (IDW PS 980), which was first published in April 2011: Institut der Wirtschaftsprüfer e.V. (IDW), Grundsätze ordnungsgemäßer Prüfung von ComplianceManagement-Systemen, IDW PS 980; see Eisolt, BB 2010, p. 1843; Görtz, CCZ 2010, p. 127; Görtz/Rosskopf, CCZ 2011, p. 103; Liese/Schulz, BB 2011, p. 1347; Merkt, DB 2014, 2331.

86 See, e.g., the standard of the German Technischer Überwachungsverein (TÜV), https:/www.tuv.com/germany/de/compliance-management.html (as of 15.8.2018).

87 See "ISO 19600 Compliance Management Systems" and "ISO 37001 Anti-Bribery Management-Systems". For details, see Makowicz, Globale Compliance Management Standards, 2018, p. $8 \mathrm{ff}$. See also the important standard on corporate social responsibility "ISO 26000 Guidance on social responsibility".

88 See, e.g., Engelhart, Sanktionierung von Unternehmen und Compliance, p. $711 \mathrm{ff}$.; Moosmayer, Compliance, 3rd edn. 2015, p. 25 ff. 
program comprises preventive measures as well as a number of control and investigative measures. It is not merely a paper program with a written code of conduct, etc. that constitutes the main difference from the business ethics movements of the 1980s. Instead, it is a companywide system that influences the entire operational and organizational structure. Ethical thinking is a vital compliance element, as ethics shape attitudes and behavior and thus determine everday routines and work. Hence, ethical behavior is also a precondition for compliant behavior. ${ }^{89}$

Control mechanisms are important but disputed aspects, especially the scope of investigative measures and sanctions. Control mechanisms are an important part of compliance measures, as they provide a routine procedure for checking the effectiveness of preventive efforts and offer the possibility to detect infringments at an early stage. But control mechanisms need to be implemented in way that does not prejudice a productive, innovative, and law-abiding corporate environment. A culture of distrust is not only economically counterproductive but also carries the risk of false accusations and fosters secret circumvention strategies. Therefore, mechanisms such as whistleblower hotlines have to be carefully constructed and implemented.

Investigative measures are useful control instruments to prevent, detect, and interrupt improper behaviour. Preventive measures remain useless when possible breaches of rules are not investigated. ${ }^{90}$ The measures applicable to compliance departments are sometimes very far-reaching, including electronic surveillance and data collection and data assessment. ${ }^{91}$ In addition, a company has extensive powers as an employer to question employees and to ask for documents, etc. Of course, the use of such measures must be legal (compliance has to be compliant), but many aspects are so far not regulated by the state in this regard. This raises questions as to whether companies can have investigative powers beyond those that would be allowed for state authorities and what the relevant criteria and restrictions are (data protection law, labor law, rights of the accused, etc.). ${ }^{92}$

Besides these measures, the nature, scope, and usefulness of internal sanctions play an important part in a compliance program. Although a company is not allowed to apply the same sanctions as the state or to apply them on behalf of the state, it can impose substantial sanctions on its own. In most cases, these are measures allowed by labor law. ${ }^{93}$ Among them are oral reprimands, formal written warnings, contractual penalties, reduction of remuneration, and suspension and dismissal. $^{94}$

89 See also Nieto Martín, Festschrift für Tiedemann, p. 485 (490).

90 See Saliger, RW 2013, 263 (267).

91 See Brazil.

92 See also in the following under III.D.

93 See Brazil. For Germany, see Sieber/Engelhart, Compliance Programs, p. 82 ff.

94 See Brazil. For Germany, see Sieber/Engelhart, Compliance Programs, p. 82. 
In practice, strict labor law rules with high protection standards for employees can undermine the efficiency of corporate compliance efforts, as seen in Brazil. ${ }^{95}$ This shows that compliance regulations should be integrated into a comprehensive approach and adjusted to existing systems.

\section{Compliance Investigations}

Compliance investigations take place when an alleged breach of the set-up rules is suspected. ${ }^{96}$ As already mentioned, such investigations are not necessarily connected to a compliance program, as they can also be taken up (and should be taken up in regard to criminal allegations) in absence of such a program if a suspicion exists or public investigations have already started. Yet, there is a close connection to compliance programs, as implemented control measures and procedures often trigger such investigations. The investigative measures of a compliance program can therefore be used to conduct the internal investigation.

Previously having regulated investigative measures in a compliance program also allows routines to be set up without the pressure of an ongoing case and with enough time to define desirable standards. The questions of who should inform who by what means under what circumstances, when public authorities should be notified, and what type of investigative measures are allowed (in order to prevent taking up illegal measures that would put the company at further risk ${ }^{97}$ ) are often not easy to determine, especially when cases are transnational and the law of several legal systems has to be taken into account.

In this regard, the following problems arise:

- Under what circumstances can investigations start? Are there situations when companies are obliged to start internal investigations? Is a suspicion needed or does the compliance staff even have total discretion to investigate without a suspicion and in cases beyond any doubt? ${ }^{98}$ Are such investigations then limited to a risk-based selection or to random inspections?

95 See Brazil.

96 See Knierim/Rübenstahl/Tsambikakis (eds.), Internal Investigations (2nd edn. 2016); Momsen, ZIS 2011, 508; Theile/Gatter/Wiesenack, ZStW 126 (2014), 803; Zerbes, ZStW 125 (2013). See also Lomas (ed.), Corporate internal investigations: an international guide (2nd edn. 2013); Webb/Tarun/Molo, Corporate internal investigations (updated 2017). For details see, e.g., Burchert, Die unternehmensinterne Befragung von Mitarbeitern im Zuge repressiver Compliance-Untersuchungen aus strafrechtlicher Sicht (2017); Oesterle, Die Beschlagnahme anwaltlicher Unterlagen und ihre Bedeutung für die ComplianceOrganisation von Unternehmen (2016).

97 Especially investigation measures bear the risk that compliance efforts are noncompliant and create legal risks for the company, see Saliger, RW 2013, 263 (279).

98 See Saliger, RW 2013, 263 (288), see also for far-reaching powers of the compliance department Brazil. 
- What investigative measures are allowed and in how far are they allowed? Is public authorization necessary or can public authorities forbid certain measures? ${ }^{99}$ This applies to open measures as well as to secret measures (corporate intelligence). Are there certain thresholds to be observed, e.g., risk criteria for installing surveillance cameras, searching e-mail communication, or data mining? Is written documentation of the factual basis of measures that are set up, of how they are conducted, or of (preliminary) results necessary? Do affected persons need to be informed after the (secret) surveillance measure ends?

- If measures are also intended to create evidence for public proceedings, are there certain standards for making evidence admissible? But also, are there possibilities to conduct mere internal investigations that need not be delivered to public authorities (even when requested), for instance seeking external advice from an attorney, resulting in communication and work products being protected by the attorney-client privilege, etc.? In general, if an external attorney is involved, when and in how far are there any privileges as regards withholding evidence?

- How can and should cooperation (from self-reporting to extensively providing evidence from internal investigations) with state authorities take place?

- What are the rights of persons affected? How much are employees obliged to cooperate; under what circumstances can they refuse to cooperate? Do they have a right to silence/protection against self-incrimination? Do they have to be informed (by some sort of Miranda warning) that their statements, etc. could be used in public proceedings? Do employees have the right to see the minutes of an interview or to comment on the interview before it is sent to a public authority? Does the possibility exist to get legal advice; is there a right to contact a lawyer or to have a lawyer present during interviews? Do rights of the individual and rights of the company have to be balanced in any way? Are fundamental rights to be observed in this relationship between private parties, or does the fundamental rights concept even have to be rethought? ${ }^{100}$

99 As it is quite clear that the use of force is reserved by the state (and insofar excludes coercive measures by a company), the aspect of a public prerogative on investigative measures is much more unclear. There are no rules forbidding private investigations, but there are some limits such as those stemming from the criminal law (see, e.g., in Germany $\S 258$ StGB - obstruction of public prosecutions and punishment; $§ 132$ Section StGB arrogation of public office; $\S 274$ StGB - supression of documents; $§ 240$ StGB - coercion). Insofar, exact limits and, in particular, public possibilities (e.g., by an investigating authority) to restrict, authorize or guide internal investigations have not yet been clarified. Yet, the utmost restrictions might stem from data protection law, especially from the General Data Protection Regulation (EU) 2016/679; in the current version of OJ L 119, 4.5.2016 (corrected OJ L 127, 23.5.2018); see Nolde, ZWH 2017, 76.

100 As fundamental rights are basically constructed as the rights of individuals against he state, these rights only apply to private parties to a very limited extent (e.g., when a protective dimension exists or when - as in Germany - a third party effect [Drittwirkung] is recognizable). See Brunhöber, GA 2010, 571 (586 f.); Bung, ZStW 125 (2013), 536 (546 ff.). 
- How do transnational settings affect investigations; which national rules govern the use of investigative measures and the rights of persons affected? Can results gained in a one country be used (if so, under what conditions) in public proceedings of another country?

These questions are very similar to those that legislators had to address when defining the role and rights of public prosecutors in criminal proceedings. Whereas constitutional rights to tame state power and clear exist in addition to often longstanding rules for public investigations and prosecutions in codes of criminal procedure, only very limited (and clear) rules exist for compliance investigations. This raises the question of whether rules for such investigations should be drawn up in the same way as for public investigations.

The situation becomes even more complex when public authorities formally request/express their expectations or just welcome internal investigations to be conducted. In complex economic criminal cases and in times of limited public resources, such internal investigations seem very attractive and even make public proceedings possible in the first place in some constellations (a transnational public investigation would often only yield very limited results). ${ }^{101}$ Also, the less defined rules and safeguards of private investigations make gathering evidence easier. Is this an illegal or illegitimate "privatization" of original state powers? Or is it allowed in certain situations (if so, which ones?) under certain circumstances (again, which ones?)? What is the impact on evidence collected; when and under what circumstances is admissibility in criminal/administrative/other proceedings prejudiced?

These questions alone show that compliance investigations are a vital part of the control mechanism within a compliance program in addition to being an important stand-alone instrument to react to alleged misconduct. This is not the place to answer these questions but only to show that many problems in regard to two major topics need to be handled when setting up a compliance program, which also need to be addressed by legislators: the type and scope of investigations measures allowed and the due protection of affected persons (mainly employees).

\section{Compliance Between Regulation and Self-Regulation}

The depiction of the legal situation in regard to compliance shows that it is often closely connected to public regulations. Insofar, one can distinguish six different levels in the state's influence state on companies and in the degree of regulative action. They range from no state influence and hence compliance as self-regulation

101 See Saliger, RW 2013, 263 (278). 
to various methods by which to trigger compliance (regulated self-regulation) and even to regulatory action by means of prescribing a compliance program: ${ }^{102}$

- Self-regulation

- Informal support by the state

- Rewarding compliance

- Sanctioning the lack of compliance

- Excluding responsibility

- General obligation to implement compliance programs.

These different levels raise the question of whether there is a common basis in making use of compliance and whether it constitutes a new regulatory approach in a similar context to the often used term of regulated self-regulation.

\section{A. Levels}

\section{Self-Regulation}

\section{a) Pure Self-Regulation}

Setting up compliance programs as a mere measure of self-regulation can be rooted in various motivations on the part of the corporation. ${ }^{103}$ One motivation might, of course, be an ethical motivation to counterbalance operational risks to society and the risks of group dynamics within organizations - by means of a coherent compliance concept and by being a "good corporate citizen." Although this might often be an additional motivational force, it is more likely that other considerations dominate. ${ }^{104}$ One might be a changing understanding of risk management that regards legal risks as a necessary part of doing business, therefore driven by aims of successful performance that is usually measured by financial success. In this sense, reducing the risks of lawbreaking and possible sanctions by fostering legal behavior is a core interest for the company.

Other motivations are also connected to company success when shareholders or market actors expect compliance efforts. It therefore becomes a key criterion for a good reputation, for being a good business partner, or it becomes a precondition (or a least a valuable asset) for joint ventures or the sale/merger of a company.

Another motivation, not to be underestimated, is trying to shift responsibility from the highest management level to the mid-management level or compliance units.

102 See Engelhart, Sanktionierung von Unternehmen und Compliance, pp. $593 \mathrm{ff}$.

103 See Rotsch, ZStW 125 (2013), 481 (485 ff.); Saliger, RW 2013, 263 (277).

104 See also Saliger, RW 2013, 263 (282) seeing ethics more as side phenomena but not as the driving force of the development. 
Although a complete delegation of duties is not possible, delegation not only makes more persons responsible for compliance issues but also often changes the nature of the duty at the highest level, from detailed responsibility to a supervisory oversight. ${ }^{105}$ Insofar, distributing responsibility is a specific form of personal risk management for the highest management level. ${ }^{106}$ In this regard, criminal risks are a strong (or even the) motivating factor. ${ }^{107}$

\section{b) “Requirements" of Private Institutions}

As the state is absent, part of self-regulation constitutes motivations that are triggered by clear compliance requirements for private institutions. Such requirements can be a precondition for participating in the market. This is the case, e.g., when stock markets (when no legal obligation exists) demand a compliance program as a precondition for being companies being listed in order to demonstrate that only companies with a comprehensive, legal risk management are on the list. Similarly, approaches like "supply chain compliance," which require suppliers to have a compliance program in order to address certain risks (e.g., excluding the purchasing of rare earth metals from conflict zones), put pressure on individual companies. In addition, many industry associations, etc. set up model compliance programs and expect or oblige their members to implement them. These model programs can contribute to setting up best practice standards and, by dissemination throughout the organization, lead to widespread application in the sector. Although a company has no obligation to participate and bind itself, the factual pressure to take part is often considerable and may in some cases have the same effect as a state regulation.

All these efforts may even have some legal relevance in litigation or in public sanctioning proceedings but they are not (at least not primarily) motivated by state action. This not only distinguishes them from the other levels, where state participation in the form of even triggering compliance and influencing the scope and content of the compliance program is given. These motivations can also be completely different from those of regulators and legislators, especially when the main emphasis is risk reduction: Covering up misconduct internally (and preventing authorities from knowing about it) is often as efficient and effective as preventing it. ${ }^{108}$ This means, for example, that a compliance program can contribute to a culture of secrecy, where compliance investigations have an important filter function, only letting out certain information to public authorities. The company thus con-

105 For details on delegation, see Schmidt-Husson, in: Hauschka/Moosmayer/Lösler, Corporate Compliance, 3rd edn. 2016, §6.

106 This motivation makes it necessary to pay extra attention to the responsibility at and control of the top management level.

107 See also Rönnau, in: Professorinnen und Professoren der Bucerius Law School (eds.), Begegnungen im Recht, 2011, p. 237 (243).

108 For this aspect, see Kölbel, ZStW 125 (2013), 499 (504 f.). 
trols whether public proceedings are taken up at all and what the scope and content of these proceedings are, especially when cooperation in individual cases is valued by public authorities more than true preventive efforts. From an economic perspective, such corporate behavior makes perfect sense but is far from regulative approaches fostering the protection of legal goods.

\section{Informal State Support}

\section{a) National System}

The next level is still close to self-regulation but, as the state in some way promotes compliance, it can be seen as the lowest level of regulated self-regulation. State support at this stage is informal, as there is support for a good corporate climate but no binding rules or clear incentives. Such support includes motivating the self-regulation of companies (by public announcements, setting up roundtables, etc.) and, more importantly, that of company associations to create best practice standards, e.g. in the banking sector. ${ }^{109}$ It also includes motivating private institutions, such as the above-mentioned stock markets, to make a good corporate and compliance structure a precondition for business.

Yet, state authorities can be of even greater help. They can advise companies on programs or set up model compliance programs. Such compliance assistance is, for example, provided by the US Environmental Protection Agency (EPA). ${ }^{110}$ Not only is the specific knowledge of administrative authorities used but regulatory expectations and ways of implementation can also be expressed. These informal incentives complement binding instruments in law enforcement as is normally the case in administrative law. Such advice is often highly welcomed by companies, as it is seen as an official push for steps in the right direction.

\section{b) Supranational System}

A separate category in this field involves "soft law" requirements for companies set up by international bodies or organizations. ${ }^{111}$ These non-binding instruments address companies and "advise" them to take up certain (sometimes very specific) measures to prevent, e.g., human rights infringements. Among these instruments

109 See, e.g., Bundesverband deutscher Banken, Best-Practice-Leitlinien für WertpapierCompliance (June 2011); see also Basel Committee on Banking Supervision, Compliance and the Compliance Function in Banks (April 2005).

110 See the Website of the EPA: http://www.epa.gov/compliance (as of 15.8.2018).

111 See O'Brien/Dhanarajan, 29 Accounting, Auditing \& Accountability Journal (2016), p. 542; Ruggie, 101 American Journal of International Law (2007), p. 819; Wetzel, Human Rights in Transnational Business, pp. 75 ff.; see also Dilling, German Law Journal 13 (2012), 381. On the corporate responsibility of corporate entities at the international level, see Ambos, Wirtschaftsvölkerstrafrecht, pp. $24 \mathrm{ff}$. 
are the OECD Guidelines for Multinational Enterprises, ${ }^{112}$ the Tripartite Declaration of Principles Concerning Multinational Enterprises and Social Policy by the International Labor Organisation, ${ }^{113}$ and the UN Global Compact Initiative in the areas of human rights, labor, the environment, and (since 2004) corruption. ${ }^{114}$ Corporate standards for implementation are provided for, e.g., by the International Standard Organisation. ${ }^{115}$

The UN has developed compliance mechanisms further since then: In 2003, the UN Sub-Commission for the Promotion and Protection of Human Rights adopted a resolution on the "Norms on the Human Rights Responsibilities of Transnational Corporations and other Business Enterprises." 116 Building on this resolution, the Human Rights Council developed a framework for promoting the topic, which builds on a on a three-tier strategy for business and human rights: protect (responsibility of states), respect (responsibility of companies), and remedy (effective possibilities to remedy damages, etc. suffered by victims of human rights violations). ${ }^{117}$ The Human Rights Council unanimously welcomed this framework in $2008^{118}$ and mandated an implementation strategy, ${ }^{119}$ which was adpoted by the Human Rights Council in June 2011. ${ }^{120}$ In addition, a Working Group on the issue of human rights and transnational corporations and other business enterprises ${ }^{121}$ and a multi-stakeholder Forum on Business and Human Rights, to be held annually

112 The guidelines were first issued in 1976; several revisions have taken place, most recently in 2011. See http://mneguidelines.oecd.org/guidelines (as of 15.8.2018). See also Ruggie/Nelson, 22 Brown Journal of World Affairs (2015), p. 99; Kasolowsky/Voland, NZG 2014, p. 1288.

113 This declaration was first adopted by the Governing Body of the International Labour Organisation at its 204th Session (November 1977); its fifth revision stems from 2017. See https://www.ilo.org/empent/areas/mne-declaration/lang--en/index.htm (as of 15.8.2018).

114 See https://www.unglobalcompact.org (as of 15.8.2018).

115 See supra note 87.

116 Resolution 2003/16 (14 August 2003), U.N. Doc. E/CN.4/Sub.2/2003/L.11 at 52 (2003).

117 In 2005, on the suggestion of the UN Commission on Human Rights, the UN Secretary General appointed John Ruggie as its Special Representative on the issue of human rights and transnational corporations. After in-depth research and consultations with many stakeholders, Ruggie presented his report "Protect, Respect and Remedy: a Framework for Business and Human Rights Report of the Special Representative of the Secretary-General on the issue of human rights and transnational corporations and other business enterprises, John Ruggie, U.N. Doc. A/HRC/8/5 (7 April 2008).

118 Human Rights Council, Resolution 8/7 (18 June 2008).

119 Again, Ruggie was mandated, and he presented his final concept in 2011: Human Rights Council, Report of the Special Representative of the Secretary-General on the issue of human rights and transnational corporations and other business enterprises, John Ruggie - Guiding Principles on Business and Human Rights: Implementing the United Nations “Protect, Respect and Remedy" Framework, U.N. Doc. A/HRC/17/31 (21 March 2011).

120 Resolution of 16 June 2011, U.N. Doc. A/HRC/Res/17/4 (6 July 2011).

121 For the Working Group see, http://www.ohchr.org/EN/Issues/Business/Pages/WGH Randtransnationalcorporationsandotherbusiness.aspx (as of 15.8.2018). 
under the guidance of the Working Group, ${ }^{122}$ was created. Part of the concept is to promote and implement the principles and further specification by the working group with national action plans. ${ }^{123}$

These international developments show the importance of international institutions in promoting compliance, not only by addressing companies directly but also by putting pressure on national systems to promote compliance. Human rights compliance has become a vital part of the compliance movement. In the future, an international treaty on this topic is conceivable: ${ }^{124}$

In 2014, the Human Rights Council established "an open-ended intergovernmental working group (OEIGWG) on transnational corporations and other business enterprises with respect to human rights, whose mandate shall be to elaborate an international legally binding instrument to regulate, in international human rights law, the activities of transnational corporations and other business enterprises." ${ }^{125}$ In July 2018, the OEIGWG presented the first draft of a legally binding instrument. ${ }^{126}$

\section{Rewarding Compliance}

At the next level come measures whereby the state rewards good compliance and thereby motivates companies to implement such programs. A rather discreet way of recognizing compliance ambitions would be legislation requiring corporations to state whether they comply with compliance rules and, if not, why not. This technique is already being used for corporate governance issues in Germany where $\S 161$ AktG requires listed companies to state if they comply with the German Corporate Governance Code or not. ${ }^{127}$ Similary, although less detailed information has to be given, §289b, c HGB (Handelsgesetzbuch - Commercial Code) large

122 See the website of the forum http://www.ohchr.org/EN/Issues/Business/Forum/Pag es/ForumonBusinessandHumanRights.aspx (as of 15.8.2018).

${ }^{123}$ For an overview, see http://www.ohchr.org/EN/Issues/Business/Pages/NationalAction Plans.aspx (as of 15.8.2018). For the proposal of a national „Human Rights Due Diligence Act for Germany“, see Klinger/Krajewski/Krebs/Hartmann, Verankerung menschenrechtlicher Sorgfaltspflichten von Unternehmen im deutschen Recht (2016).

124 See Deva/Bilchitz (eds.), Building a Treaty on Business and Human Rights (2017); La Vega, 51 University of San Francisco Law Review (2017), p. 431; Lopez/Shea, 1 Business and Human Rights Journal (2016) (1), p. 111.

125 Human Rights Council, Resolution 26/9 of 26 June 2014, HRC Res. A/HRC/RES/26/9. On the OEIGWG, see https://www.ohchr.org/EN/HRBodies/HRC/WGTransCorp/Pages/IGW GOnTNC.aspx (as of 15.8.2018).

126 See the draft of the "Legally Binding Instrument to Regulate, in International Human Rights Law, the Activities of Transnational Corporations and Other Business Enterprises" https://www.ohchr.org/Documents/HRBodies/HRCouncil/WGTransCorp/Session3/DraftLBI .pdf (as of 15.8.2018).

127 The German Corporate Governance Code (Deutscher Corporate Governance Kodex) is available under https://www.dcgk.de/de/kodex.html (as of 15.8.2018). 
companies have to report their activities in regard to human rights and sustainable development. A precondition for the use of such a regulatory technique is to have detailed enough compliance requirements in order to be implementable. Insofar, some form of corporate compliance code is needed ${ }^{128}$ comparable to the ones established in the field of corporate governance German Corporate Governance Ko$\mathrm{dex}^{129}$ or recently in the field of sustainable development and human rights (German Sustainability Code) ${ }^{130}$.

Such measures rewarding compliance exist especially in criminal liablity structures and, in cases of corporate liablility, provide a major incentive for corporations. An example of corporate criminal liability is when authorities refrain from initiating proceedings or close proceedings when compliance measures show that the company had done what it possibly could to prevent the illegal act of a member of the company. As it is never possible to completely rule out illegal acts within a company, one has to evaluate whether the company had taken reasonable steps before the act was committed (ex ante approach). In the USA, the United States Attorneys' Manual offers federal prosecutors precisely such a possibility for the dismissal of charges (although the affected company almost always has to accept some conditions of probation). ${ }^{131}$

Compliance can also be important at the sentencing stage, e.g. in the Corporate Federal Sentencing Guidelines in the USA or for corporate sanctions in Japan. ${ }^{132}$ In particular, when a sentencing authority has the discretion to take the scope and effectiveness of compliance measures into account, it can evaluate how much the corporate climate influenced the wrongdoing, how much was due to unforeseeable individual behavior, and how strong the measures to prevent such behavior were. Only granting a reduction if a comprehensive and effective program exists not only seems too inflexible but also reduces the incentive to implement at least some measures.

In addition to the law of sanctions, administrative law can also provide incentives, for example by reducing public supervision. One incentive could be to extend the period for public controls from two to four years if an effective compliance program exists.

128 See Engelhart, Sanktionierung von Unternehmen und Compliance, p. 652 for the proposal to set up a private-public corporate compliance commission that could set up requirements in form of a corporate compliance code.

129 See supra note 127.

130 The German Sustainability Code (Deutscher Nachhaltigkeitskodex) is available under https://www.dcgk.de/ (as of 15.8.2018).

131 See United States Attorneys' Manual (USAM), § 9-28.800 and § 9-28.1500.

132 See supra III.B.2. 


\section{Sanctioning the Lack of Compliance}

The lack of due compliance becomes relevant when public institutions make the existence of a compliance program a precondition for access to funding, granting loans or public contracts. This has long been practiced by international organizations. ${ }^{133}$ From a regulatory perspective, non-compliance is sanctioned by exclusion from possible financial and non-financial benefits.

Taking into consideration the lack of due compliance as an aggravating factor at the sanctioning stage also takes the approach of regulated self-regulation one step further. The lack of compliance as an aggravating factor is possible, for example, when compliance measures are merely undertaken to give the company the appearance of being a good corporate citizen but are, in practice, ineffective and merely window dressing. Lack of compliance as an aggravating factor can also be taken into account when the company does not take concrete action, even though obvious risks of lawbreaking exist and were recognisable. Such rules clearly send the message that neither misleading measures nor too risky business is acceptable or tolerated.

The most direct way to address the lack of compliance is the use of a specific compliance sentence comprising the obligation to implement certain compliance measures or a comprehensive compliance program. The US Federal Sentencing Guidelines and the practice of federal prosecution in the USA often serve as examples for such an approach. ${ }^{134}$ This allows the sanctioning authority to directly influence the corporate structure and address the deficiencies that led to wrongdoing. It also enables a genuine resocialization of the company, something that is much more difficult to achieve when the accused is an individual. The threat of such a sanction effecting structural reforms is a great incentive for companies to proactively take up efficient compliance measures and is often much more effective than monetary sanctions.

\section{Excluding Responsibility}

One of the greatest incentives for compliance are rules that exclude (corporate) responsibility if efficient compliance measures are taken. Such regulations can be seen in corporate law and have become increasingly popular in recent years for corporate criminal liability. ${ }^{135}$ Regulation in this case goes beyond denying benefits but it sanctions non-compliance.

Besides creating strong incentives, this approach is often a just and fair solution. For instance, corporate criminal liability only applies when the corporate climate

133 Nieto Martín, in: Kuhlen/Kudlich/Ortiz de Urbina (eds.), Compliance und Strafrecht, p. 27 (29).

134 See supra III.B.2.

135 See supra III.B.2. 
has contributed to the offense (the entity can then be literally called "guilty"). In this case, the company may not be liable but an individual still can be, yet the company might still be held responsible for civil damages under a civil liability regime: Rules for damages are based on a different rationale (in particular, risk distribution) than sanctioning systems with their emphasis on social blame. In addition, such an approach shows that different standards apply to corporate and individual liability, a difference that can also be used when determining administrative responsibility or civil damage liability: Corporate responsibility specifically addressess the general corporate environment, whereas individual liability concentrates on specific actions within this environment.

Of course, the exclusion of liability is only possible if the compliance measures meet the necessary (high) standards that can be reasonably expected in the corporate environment. The expectation is for companies to truly and seriously invest in effective compliance measures. Since such an expectation might deter some companies from investing in compliance, this type of regulation should only be taken up in addition to other steps that also create incentives for implementing individual measures or measures of a less high standard.

\section{General Obligation to Implement Compliance Programs}

On a last level, general (enforceable) obligations to implement compliance programs exist. The strongest influence can be achieved if such an obligation is not only enforceable (e.g., by administrative agencies) but also accompanied by a sanction in case of insufficient implementation. This approach is at the upper margin of regulated self-regulation and closely approximates classic "regulation." Selfregulation in this case mainly means that the company can determine elements of the compliance program not prescribed by law.

Whereas such a broad general obligation (to respect the law in general) does not seem to exist at present, sector obligations are already common, although they vary considerably in detail. ${ }^{136}$ For example, the German Securities Trading Act requires financial institutions to set up compliance measures for the prevention of insider trading and punishes non-implementation with an administrative fine. ${ }^{137}$ This was one of the first examples of Germany's new preventive tendencies in fighting economic crime. ${ }^{138}$

136 In addition to the examples in the text, see also supra III.B.1.

137 See $\S 80$ para. 1 s. 2 No. 1 , $\S 120$ para. 8 No. 97 Securities Trading Act (Wertpapierhandelsgesetz - WpHG as of 15.8.2018).

138 Vogel, Festschrift für Jakobs, pp. $731 \mathrm{ff}$. therefore refers to the emergence of a new criminal law model. 
Similary, Portugal's anti-money laundering law requires companies to set up compliance programs and punish the lack of implementation with a fine ${ }^{139}$ In contrast, Colombia's anti-bribery law (regulating the administrative liability of legal entities for transnational corruption) provides for an obligation to take up preventive compliance measures ${ }^{140}$ but does not directly sanction non-implementation. ${ }^{141}$ Furthermore, the German Federal Immission Control Act requires companies operating plants subject to licensing to set up a control system, to inform the authorities about it, and to have it regularly checked and approved by the authorities. ${ }^{142}$

The lack of a general obligation to set up compliance programs may be an indication of the legislator's discomfort with substantially interfering in companies' right of freedom of business. From this perspective, it is preferable to make compliance obligatory only in specific areas in which the legislator deems it absolutely necessary in order to effectively regulate the sector. Such an obligation seems necessary when the aforementioned measures do not provide enough incentives for legal behavior or when the protected legal goods in question warrant special measures.

\section{B. Towards a General Compliance Theory}

\section{Self-Regulation and its Limits}

In a society based on individual rights and a free-market society, economic activities are basically free of any state influence. Self-regulation is therefore the rule and regulation the exception. Of course, regulation is often inevitable, especially in the corporate environment, e.g. granting models for legal personhood. But regulation needs justification in such a setting. In this case, the question of why setting up compliance programs should not be left to companies alone is justified.

There are two main aspects that justify regulation: power and corporate climate. These aspects also constitute major differences from the treatment of individuals, hence allowing a stricter approach in regard to companies. Companies are an agglomerate of goods and people. This not only gives them financial power but also especially because of their often specialized and highly qualified personnel - farreaching possibilities to influence the markets, the media, public discussion, and sometimes even politics and law-making. Such power can be used to influence others and to jeopardize the rights of less powerful individuals and companies.

\footnotetext{
139 See Portugal, referring to Law 83/2017.

140 See Colombia, referring to Law 1778 of 2016.

141 However, it does play a role on sanctioning; see supra note. 65.

142 See $\S 52$ a Bundesimmissionsschutzgesetz (BImSchG). For details, see Bosch, Organisationsverschulden in Unternehmen, pp. $520 \mathrm{ff}$.
} 
Another aspect of the corporate climate sees companies as being an agglomerate of people in a structured environment. Social sciences, such as the works by Luhmann on the system theory, ${ }^{143}$ have shown that a company is a system of its own. ${ }^{144}$ It exists alongside other systems and, most relevant in this context, alongside the legal system. Companies have their own rules and procedures. Teubner calls it "law without state." "145 This often means that a private and a public system of norms govern the corporate sphere.

The existence of a separate corporate system has the consequence that group dynamic processes can develop independently from other systems. Group dynamics are the result of the interaction of several people and result in the creation of group will, which results in a specific corporate climate. Organizational psychology ${ }^{146}$ and criminological research ${ }^{147}$ show that such a climate can be maintained for a long period of time, is experienced by individual members of the organization, and can greatly influence personal behavior. The business ethics development has also highlighted the importance of the attitudes of employees and what influences their behavior.

The corporate climate can have a positive and a negative influence on the members of the organization. If the values and rules are the same as those in the legal system, the corporate climate supports members acting legally. If not, when making a profit is tacitly agreed and subtly seen as the main (and maybe only) value, such a climate erodes the legal thinking and actions of the group members. If such an erosion of values goes hand in hand with corporate powers, the risk of breaking the law with severe consequences is high. Power and corporate climate therefore justify state intervention and state regulation.

As shown by the development of compliance, the need for state intervention is felt more often today than in decades before so that there is a clear tendency to move away from mere self-regulation towards more state control. One could even

143 See Luhmann, Die Wirtschaft der Gesellschaft, pp. 43 ff. and Luhmann, Das Recht der Gesellschaft, pp. 38 ff. It has been argued, e.g., that self-regulation, etc. can be understood without reference to system theory; see Kuhlen, in: Kuhlen/Kudlich/Ortiz de Urbina (eds.), Compliance und Strafrecht, p. 1 (14). This is quite true, yet system theory provides a sound description of the different features and structures within a corporation. Also, the system theory is mainly descriptive and insofar not of much helf for shaping legal theories, see, e.g., Saliger, RW 2013, 263 (283).

144 See Boers, MschrKrim 2001, p. 335 (353); Gómez-Jara Díez, ZStW 119 (2007), p. 290 (302 ff.); Heine, Verantwortlichkeit von Unternehmen, pp. 79 ff.; Sieber, Festschrift für Tiedemann, p. 449 (475).

145 Teubner, Global law without a state (1997).

146 See, e.g., Rosenstiel, Organisationspsychologie, pp. 387 ff.; Spieß/Winterstein, Verhalten in Organisationen, pp. $121 \mathrm{ff}$.

147 See, for more details, Engelhart, Sanktionierung von Unternehmen und Compliance, pp. 515 ff., 768 ff.; Kölbel, ZStW 125 (2013), 499; Kölbel, MschKrim 91 (2008), pp. 22 ff.; Theile, ZIS 2008, 406. 
say the era of self-regulation has vanished. For example, the efforts of the business ethics movement to motivate managers to act more ethically were often not effective, especially at times when managers or companies were under (economic) pressure. Insofar, ethical behavior is easy in good years but not in difficult business years. In the latter case, the financial interests of the company often prevail: good will and legal and ethical rules are readily set aside. This economic perspective also illustrates a fundamental difference in motivation in comparison to regulators that primarily focus on the protection of legal goods. The difference in motivation is hardly possible to overcome other than by setting up regulation.

Yet, even if justification for state intervention is given, this does not say anything about how it should be achieved. Precisely in this regard, classic regulation, with its simple "do that/do not do that or you will be punished" approach is often too short-sighted. Since companies are separate systems of their own, such regulations in the legal system neither easily nor effectively influence internal behavior, as they may not reach the internal level and penetrate the corporate climate of the company. As is often stated, these types of regulations do not "pierce the corporate veil." 148 Of course, one could stop here and merely expect corporations to respect the law and bear the consequences in the form of administrative action and civil and criminal liability. A traditional approach would be just to create more rules of this kind, e.g. new criminal offenses for new phenomena. Although such legislation might fill some loopholes, it does not address corporate behavior well and also does not solve the underlying social problems. The way out of non-effective selfregulation and regulation is provided by the concept of compliance as an approach of regulated self-regulation.

\section{Compliance as Regulated Self-Regulation}

\section{a) Concept}

The tension between self-regulation and regulation can be resolved by taking the middle ground: compliance as regulated self-regulation. ${ }^{149}$ This approach builds on a discussion of the ideas of "responsive regulation" 150 and "interactive compliance."151

148 See, e.g., Alting, 2 Tulsa Journal Comparative \& International Law 187 (1994-1995).

149 See Engelhart, Sanktionierung von Unternehmen und Compliance, p. 649 ff.; Engelhart, RW 2013, 208; Rotsch, ZStW 125 (2013), 481 (496); Saliger, RW 2013, 263 (283 ff.); Sieber, Festschrift für Tiedemann, p. 449 (460); Wessing, Festschrift für Volk, p. 880. Only partly agreeing: Kölbel, ZStW 125 (2013), 499 (507), as corporations have no great influence on the rules that are part of compliance programs. See also Black, Current Legal Problems 2001, p. 103, 120 f.; Parker/Nielsen, Annual Review of Law and Social Science 2009, p. 45 (48 f.); Krawiec, Washington University Law Quarterly 81 (2003), p. 487 (516 ff.).

150 Ayres/Braithwaite, Responsive Regulation, pp. 101 ff. See also Braithwaite, 80 Michigan Law Review 1466 (1982).

151 Sigler/Murphy, Interactive corporate compliance, pp. 169 ff. 
The discussion bridged the conflicting sides of regulation and self-regulation by offering new ways for complex and internationalized settings such as those in the economic sector. ${ }^{152}$ They have been increasingly recognized, for example in German administrative law ${ }^{153}$ and more recently in criminal law, ${ }^{154}$ constituting a paradigm shift by "regulating" the preliminary stages of a criminal act. ${ }^{155}$ Compliance insofar bridges the antagonistic concepts of repression and prevention.

This approach builds on self-regulatory measures but within an overall regulative concept of steering and stimulating corporate behavior while at the same time allowing companies the flexibility to implement and individually adjust measures. ${ }^{156}$ The state does not wait until self-regulation takes hold but instead actively triggers and shapes its development. However, as is the case with self-regulation, it gives companies the benefit of the doubt, as it waives the introduction of more intrusive regulations. ${ }^{157}$ Companies and the state work together on setting down rules and standards (standardization process) and on implementing measures to achieve these standards (implementation process), so that the process covers all aspects of traditional regulation. ${ }^{158}$ The state treats companies as an important, in fact even as the main partner in achieving law abidance.

According to this concept, the state imposes the fundamental framework for compliance, whereas the companies are responsible for regulating the details. It requires companies not only to respect legal regulations but also to actively contribute to the prevention of legal infringements, especially crimes. As the concept does not go into detail on how to accomplish this, it does not unnecessarily impair legitimate business dealings. Due to the involvement of private actors (at least more than in the past) one can speak to a certain extent of the privatization of state duties. ${ }^{159}$ Yet, in substance privatization mainly concerns compliance investigations whereas the field of prevention has been left more or less completely to the

152 See Nieto Martín, Festschrift für Tiedemann, p. 485 (487).

153 Eifert, in: Hoffmann-Riem/Schmidt-Aßmann/Voßkuhle (eds.), Grundlagen des Verwaltungsrechts. Vol. I, p. 1318 (1345 ff.); Hoffmann-Riem, Festschrift für Reiner Schmidt, pp. 447 ff.; Voßkuhle, Verwaltungsarchiv 92 (2001), pp. 184 (213).

154 See Engelhart, Sanktionierung von Unternehmen und Compliance, pp. 645 ff.; Sieber, in: Waltermann/Machill (eds.), Protecting our children on the internet, p. 319 (326).

155 Engelhart, RW 2013, 208; Rotsch, ZStW 125 (2013), 481.

156 This also includes empirical evidence, namely that self-regulation is most successful when accompanied with advice, supervision, and sanctions by public authorities; see Kölbel, ZStW 125 (2013), 499 (506 ff.); Schulz/Held, Regulierte Selbstregulierung als Form modernen Regierens, p. $61 \mathrm{ff}$.

157 Kölbel, ZStW 125 (2013), 499 (529 f.).

158 Rule-setting and enforcement measures are the basic aspects of regulation; in the context of compliance, see Kölbel, ZStW 125 (2013), 499 (506 ff.).

159 See, e.g., Saliger, in: Professorinnen und Professoren der Bucerius Law School (eds.), Begegnungen im Recht, 2011, p. 215 (219 ff.). 
companies before. Insofar, the compliance approach in this regard is more the nationalisation of an un-/under-regulated part of the field of crime prevention.

By means of this construction, the problem of the state not having a direct influence on the internal company structure and its corporate climate is solved. The state encourages companies to make the internal actions of their employees more visible and to create an atmosphere being watched constantly. ${ }^{160}$ As Foucault showed, this type of visibility is such a powerful instrument that it often no longer needs the actual execution of powers such as sanctions, etc. ${ }^{161}$ Within in such a "culture of control," 162 companies assume an important role in social control, whereas the state remains in a sort of managerial position with oversight duties. In essence, this social control mechanism is situational crime prevention, the main emphasis being on risk detection in (at least perceived) risk-entailing situations and on enhancing the resistance to risky behavior. ${ }^{163}$ The state activates preventive approaches in order to stabilize its own normative system.

The objective of the approach is the creation or maintenance of a good corporate climate fostering the adherence to regulations (compliance). ${ }^{164}$ It makes use of the "good" dynamics within the closed social system of a company. Compliance programs are of great importance towards achieving such a good corporate climate, as they provide an effective tool for preventing and detecting legal infringements within companies. Compliance is therefore a model means of regulated selfregulation, as it allows the state to set a framework for corporate compliance structures that are necessary for a good corporate climate - without prescribing them in detail. This makes it manageable (and cost-efficient) for the state, while at the same time leaving room for companies and their individual business, risks, size, and corporate structure. Compliance reduces risks to a legally acceptable level, as it decreases the anticipated loss value mainly by reducing the probability of infringements. ${ }^{165}$ Compliance programs are therefore social control measures to prevent deviant behavior within organizations: ${ }^{166}$ they minimize the opportunities to commit crimes and maximize incentives to follow the rules.

160 See Bung, ZStW 125 (2013), p. 536 (539).

161 Foucault, Überwachen und Strafen, p. 260.

162 See Garland, The Culture of Control, p. $167 \mathrm{ff}$, , building on the ideas of Foucault. See further for this new type of "modern interventionist state" Zabel, KritV, p. 18 (28 ff.).

163 Kölbel, ZStW 125 (2013), 499 (502); Singelnstein, KJ 2011, 7 (12). See also Nieto Martín, Festschrift für Tiedemann, p. 485 (488); Saliger, RW 2013, 263 (291).

164 See also Bussmann, Festschrift für Achenbach, pp. $57 \mathrm{ff}$. and Bussmann/Salvenmoser, CCZ 2008, pp. 192 ff.

165 The expected loss value is the product of the expected loss multiplied by its probability of occurring. See Bock, Criminal Compliance, pp. $484 \mathrm{ff}$.

166 See Nieto Martín, in: Kuhlen/Kudlich/Ortiz de Urbina (eds.), Compliance und Strafrecht, p. 27 (35), also stating that criminology could therefore perfectly contribute to the construction of effective compliance programs. See also Saliger, RW 2013, 263 (277). 


\section{b) The Use of Criminal Law}

Basically, the legislator has the possibility to implement the approach of regulated self-regulation in private law, administrative law, and the law of public sanctions. ${ }^{167}$ Yet, not all of these areas of law are equally suitable. Private law offers only a low number of possibilities to steer company behavior. It leaves too many aspects to the discretion of the parties and is generally money-oriented, especially the law of torts. Exceptions are, e.g., rules on the duties of a managerial board to take up compliance measures. ${ }^{168}$ Implementation in administrative law, however, leads to strong state influence, as any rules would be directed at all companies, and a state authority would have to be responsible for controlling these companies. Resorting to less intrusive measures, such as prescribing a certain aim in the preamble, provides only limited steering possibilities and effects. ${ }^{169}$ Therefore, private and administrative law mainly have a supporting function in an overall approach of regulated self-regulation.

The best place to regulate is the law of public sanctions as an indirect implementation system: ${ }^{170}$ although it addresses all companies and its members, the rules only become relevant if there is suspicion of an infringement. The allocation of public resources is more efficient, and state interference with companies' rights is lower than in the case of administrative regulations. In the context of criminal law, it offers the possibility to steer company behavior by means of motivation, if incentives for implementing measures are included into the concept. In this regard, criminal compliance fits into the general trend towards "risk criminal law."171 The approach also includes newer constructions for corporate criminal liability, building on the corporate climate in its own corporate system. ${ }^{172}$

167 The advantages and disadvantages of such a legislative choice have rarely been discussed, as the main focus is on the distinction between public and private law and on the (constitutional) limits of such measures. It therefore only addresses a small aspect of the subject, especially in regard to criminal law. For a basic analysis of the different legal regimes, see Burgi, in: Hoffmann-Riem/Schmidt-Aßmann/Voßkuhle (eds.), Grundlagen des Verwaltungsrechts, Vol. I, pp. 125 ff.; Hoffmann-Riem, Festschrift für Jung, pp. 299 ff.; Waldhoff, in: Hoffmann-Riem/Schmidt-Aßmann/Voßkuhle (eds.), Grundlagen des Verwaltungsrechts, Vol. III, pp. 269 (381 ff.).

168 See supra III.B.1.

169 On this frequently used technique in German adminstrative law, see, e.g., Schober, Der Zweck im Verwaltungsrecht, pp. $236 \mathrm{ff}$.

170 Nieto Martín, in: Kuhlen/Kudlich/Ortiz de Urbina (eds.), Compliance und Strafrecht, p. 27.

171 Kuhlen, in: Kuhlen/Kudlich/Ortiz de Urbina (eds.), Compliance und Strafrecht, p. 1 (14); Rotsch, ZStW 125 (2013), 481 (495); see also Saliger, RW 2013, 263 (282).

172 See Engelhart, Sanktionierung von Unternehmen und Compliance, pp. 685 ff. referring to the corporate climate, Gómez-Jara Díez, ZStW 119 (2007), p. 290 (293 ff.) referring to the self-reference of the corporate system (based on the theory of autopoetic systems); Ortmann, NZWiSt 2017, 241 referring to the organization theory. 
Developing criminal law to include compliance is especially fitting in cases of economic crimes. Economic criminal law is the traditional accessory to obligations set out by public and civil law. ${ }^{173}$ Hence, criminal compliance does not create additional obligations but fulfills existing ones to a large extent and promotes the consistency of the legal order. Insofar, it is also less oriented towards the definition of the offense (especially the description of the act) than towards fulfilling underlying duties. This can be seen as being a perfect expression of the ultima ratio principle.

Resorting to public criminal sanctions in order to increase the willingness to take up compliance measures of course makes use of the traditional mechanism: the threat of a sanction. ${ }^{174}$ Expanding and more complex and diffuse criminal law contributes to compliance insofar as it creates more threats. ${ }^{175}$ The deterrent and preventive effect of, e.g., corporate criminal liability, although often disputed, ${ }^{176}$ was already proven empirically in the 1970 s by Breland and Tiedemann ${ }^{177}$ and by recent research at the Max Planck Institute for Foreign and International Criminal Law confirming that criminal law measures are more effective than imposing administrative or civil sanctions. ${ }^{178}$ Criminal compliance uses this mechanism but goes beyond it by providing additional incentives. Insofar, criminal compliance mobilizes corporate mechanisms in order stabilize its own criminal law values and confirm its own validity.

\section{c) Limits and Problems}

But what are the limits of this concept? First of all, no one is obligated to do more than he is able to (ultra posse nemo obligatur). Compliance cannot mean that organizations must take precautions for any risks; unforseeable risks especially cannot be part of a compliance strategy. The law may create rules for damages, etc., even covering such risks on a strict liability basis (as they stem from the corporate sphere, and it seems to be fair that the corporation bear the consequences for it), but it is not possible to address such risks in the compliance context. Compliance can address foreseeable risks but even among them, a certain

173 See Achenbach, StV 2008, 324; Nieto Martín, in: Kuhlen/Kudlich/Ortiz de Urbina (eds.), Compliance und Strafrecht, p. 27 (33).

174 Kölbel, ZStW 125 (2013), 499 (517).

175 Kölbel, ZStW 125 (2013), 499 (517).

176 See, e.g., Hefendehl, ZStW 119 (2007), p. 816 (826 ff.), more positively Roxin, Strafrecht, § 3 para. 25; see also Engelhart, Sanktionierung von Unternehmen und Compliance, pp. $277 \mathrm{ff}$., $661 \mathrm{f}$.

177 See Breland, Lernen und Verlernen von Kriminalität (1975); Tiedemann, Wirtschaftsstrafrecht und Wirtschaftskriminalität, p. 249; see also Tiedemann, in: Brodowski et al. (eds.), Regulating Corporate Criminal Liability, 2014, p. 11.

178 See Sieber/Engelhart, Compliance Program, pp. $162 \mathrm{ff}$., $178 \mathrm{ff}$., confirming that criminal measures are more effective than imposing administrative or civil sanctions. 
selection might be advisable for compliance to be a workable concept. Compliance is a promising concept but not without limitations.

Also, compliance can only work if the legislator or regulator sets up operable criteria for compliance programs. In order to have a steering effect, these criteria must be more detailed than due duty of care or oversight or negligence standards. But this also means that compliance creates rules that are often above existing general standards such as in criminal law. ${ }^{179}$ But what to do, when there is no clear best practice standard? Setting up rules in this situation might exclude other solutions equally effective (creating conformity for the price of flexibility). Also, companies will often take the highest standard in order to be "on the safe side". This sounds promising and especially in a transnational context it triggers legal harmonization (when companies operating in different jurisdictions take the highest standard in order to make sure that they are compliant in all circumstances). ${ }^{180}$ But this also means, that foreign concepts can determine the own national system that might have explicitly voted for a certain (lower) standard or flexible concept. Under the umbrella of fostering the international compliance development national policy concepts might be (aggressively) be promoted abroad.

And, operable compliance standards must be adjusted to other concepts in order to avoid undermining the compliance approach. This means, e.g., no one-sided emphasis on control measures in order to avoid a culture of distrust within organizations. How should the doubling of sanction norms and regimes to be dealt with? ${ }^{181}$ Is there a ranking between internal and external sanctions, do we need a ne bis in idem regulation?

Furthermore, cooperation obligations, pressure, or incentives from public authorities in case of an incident must be balanced with preventive efforts: As long as cooperation does companies more good than compliance, there is no real incentive for (costly) compliance. In addition, the question of illegitimate privatization of state functions has to be taken into account. Neither cooperation nor compliance requirements can be used to circumvent standards of criminal procedure. Seeing the corporation as a system of its own with all manner of facets, from from law-making to enforcement, is cause for thought about necessary rules for procedure in compliance investigations, etc., like in the state system. ${ }^{182}$ A corporation that is a lawmaker, police officer, investigator, judge, and enforcement agency all in one needs some checks and balances in regard to such an agglomeration of power.

\footnotetext{
179 Saliger, RW 2013, 263 (285).

180 Saliger, RW 2013, 263 (288).

181 Kölbel, ZStW 125 (2013), 499 (530 f.).

182 See, e.g., Kuhlen, in: Kuhlen/Kudlich/Ortiz de Urbina (eds.), Compliance und Strafrecht, p. 1 (19 ff.).
} 
But even when there are sound criteria for compliance programs, is the (criminal) justice system capable of determining the effectiveness of a compliance program? Or, as Hassemer said once, is it rather that "criminal law is good for the protection of legal goods but not for risk governance, its measures are good for investigations but not for prognosis"? ${ }^{183}$ In practice, the question of effectiveness is indeed a difficult one, as special expertise is needed. ${ }^{184}$ Insofar, adjustments to the criminal justice system in order to provide specialized investigators, prosecutors, and judges are needed.

But external expertise can also help. It is useful when setting up the compliance system and especially as a means of gatekeeping with monitoring and adapting the program continuously. In an ideal system of regulated self-regulation, the state would in some way be continuously involved in monitoring and adapting the program. ${ }^{185}$ Yet, as criminal law responds selectively, sporadically, and reactively also in regard to limited public resources - this is only possible in a very limited way. External evaluation is therefore inevitable. Such expertise may then again be valuable in public proceedings in order to assist sanctioning authorities. Of course, the recourse to experts creates new questions in conjunction with the possibility of shifting risk to advisors and the creation of a special sort of advisor liability. ${ }^{186}$

183 Hassemer, ZRP 2009, 221 (222).

184 The existing judicial practice of evaluating compliance programs has not been too promising so far, as it often remains rather vague on their (non)effectiveness; see Nieto Martín, in: Kuhlen/Kudlich/Ortiz de Urbina (eds.), Compliance und Strafrecht, 2012, p. 27 (46). There are, however, some promising judgements such as that in the Siemens corruption case (see the "Neubürger judgment" of LG München I, Decision of 10 December 2013 - 5 HKO 1387/10 - ZIP 2014, 570), indicating that it may take some time for the judiciary to become familiar with the topic.

185 See Kölbel, ZStW 125 (2013), 499 (527).

186 See already Nieto Martín, Festschrift für Tiedemann, p. 485 (496 f.). 


\section{Bibliography}

Achenbach, Hans, Die wirtschaftsstrafrechtliche Reformbewegung - ein Rückblick. In: Ulrich Sieber/Gerhard Dannecker/Urs Kindhäuser/Joachim Vogel/Tonio Walter (eds.), Strafrecht und Wirtschaftsstrafrecht - Dogmatik, Rechtsvergleich, Rechtstatsachen. Festschrift für Klaus Tiedemann zum 70. Geburtstag. Köln/München 2008, pp. 47-60.

- „Ordnungsfaktor Wirtschaftsrecht”. Strafverteidiger (StV) 2008, pp. 324-327.

Almond, Paul, Corporate Manslaughter and Regulatory Reform. Houndsmills, Basingstoke, Hampshire 2013.

Alting, Carsten, Piercing the corporate veil in German and American law - Liability of individuals and entities: a comparative view. 2 Tulsa Journal Comparative \& International Law (1994-1995), pp. 187-252.

Ambos, Kai, Wirtschaftsvölkerstrafrecht. Grundlagen der völkerstrafrechtlichen Verantwortlichkeit von Unternehmen. Berlin 2018.

Arroyo Zapatero, Luis/Nieto Martín, Adán (eds.), El derecho penal económico en la era compliance. Tirant lo Blanch. Valencia 2013.

Arzt, Gunther, Siemens: Vom teuersten zum lukrativsten Kriminalfall der deutschen Geschichte. In: Matthias Jahn/Hans Kudlich/Frank Streng (eds.), Festschrift für Heinz Stöckel zum 70. Geburtstag, Berlin 2010, pp. 15-42.

Arzt, Gunther et al. [ed.], Entwurf eines Gesetzes zur Regelung der Betriebsjustiz. Tübingen 1975 .

Ayres, Ian/Braithwaite, John, Responsive regulation: transcending the deregulation debate. Oxford et al. 1995.

Bacigalupo, Enrique, Compliance und Strafrecht in Spanien. In: Thomas Rotsch (ed.), Compliance-Diskussion. Baden-Baden 2012, pp. 135-145.

Bacigalupo, Enrique, Compliance y derecho penal. Cizur Menor (Navarra) 2011.

Beale, Sara Sun, Die Entwicklung des US-amerikanischen Rechts der strafrechtlichen Verantwortlichkeit von Unternehmen. Zeitschrift für die gesamte Strafrechtswissenschaft (ZStW) 126 (2014), pp. 27-45.

Birnbaum, Günter/Kütemeier, Claire, In der Diskussion - die MaComp. WertpapierMitteilungen (WM) 2011, pp. 293-299.

Black, Julia, Decentring Regulation: Understanding the Role of Regulation and SelfRegulation in a 'Post-Regulatory' World. Current Legal Problems 54 (2001), pp. 103-146.

Bock, Dennis, Criminal Compliance. Baden-Baden 2011.

- Stand der strafrechtswissenschaftlichen Compliance-Diskussion in Deutschland. In: Thomas Rotsch (ed.), Compliance-Diskussion. Baden-Baden 2012, pp. 63-76. 
Boers, Klaus, Wirtschaftskriminologie. Vom Versuch, mit einem blinden Fleck umzugehen. Monatsschrift für Kriminologie und Strafrechtsreform (MschrKrim) 2001, pp. 335-356.

Bosch, Nikolaus, Organisationsverschulden in Unternehmen. Baden-Baden 2002.

Bovermann, Wolf-Dieter, Die „Betriebsjustiz“ in der Praxis. Köln 1969.

Braithwaite, John, "Enforced Self-Regulation: A New Strategy for Corporate Crime Control”, 80 Michigan Law Review (1982), pp. 1466-1507.

Breland, Michael, Lernen und Verlernen von Kriminalität. Opladen 1975.

Brown, H. Lowell, The Corporate Director's Compliance Oversight Responsibility in the Post Caremark Era. 26 Delaware Journal of Corporate Law (2001), pp. 1-145.

Brunhöber, Beatrice, Privatisierung des Ermittlungsverfahrens im Strafprozess. Goltdammer's Archiv für Strafrecht (GA) 2010, pp. 571-588.

Bung, Jochen, Grundlagenprobleme der Privatisierung von Sanktions- und Präventionsaufgaben. Zeitschrift für die gesamte Strafrechtswissenschaft (ZStW) 125 (2013), pp. 536-550.

Burchert, Christoph, Die unternehmensinterne Befragung von Mitarbeitern im Zuge repressiver Compliance-Untersuchungen aus strafrechtlicher Sicht. Berlin 2017.

Burgi, Martin, Rechtsregime. In: Wolfgang Hoffmann-Riem/Eberhard Schmidt-Aßmann/ Andreas Voßkuhle (eds.), Grundlagen des Verwaltungsrechts. München 2012, pp. 12571318.

Bussmann, Kai-D., Business Ethics und Wirtschaftsstrafrecht. Monatsschrift für Kriminologie und Strafrechtsreform (MschrKrim) 2003, pp. 89-104.

- Sozialisation in Unternehmen durch Compliance. In: Uwe Hellmann/Christian Schröder, (eds.), Festschrift für Hans Achenbach. Heidelberg et al. 2011, pp. 57-82.

Bussmann, Kai-D./Salvenmoser, Steffen, Der Wert von Compliance und Unternehmenskultur. Corporate Compliance Zeitschrift (CCZ) 2008, pp. 192-196.

Carbonell Matau, Juan Carlos, Die strafrechtliche Verantwortlichkeit juristischer Personen: Überlegungen zur „Dogmatik“ und zum System der Reform des spanischen Strafgesetzbuchs 2010. Zeitschrift für die gesamte Strafrechtswissenschaft (ZStW) 123 (2011), pp. 331-346.

Castaldo, Andrea R., Die aus Straftaten entstehende verwaltungsrechtliche Haftung der Unternehmen nach der italienischen Rechtsreform vom Juni 2001. Zeitschrift für Wirtschafts- und Steuerrecht (wistra) 2006, pp. 361-365.

Dannecker, Gerhard/Leitner, Roman (eds), Handbuch der Geldwäsche-Compliance. Wien 2010.

de Maglie, Christina, Societas Delinquere Potest? The Italian Solution. In: Mark Pieth/Radha Ivory (eds.), Corporate Criminal Liability. Emergence, Convergence, and Risk. Dordrecht 2011, pp. 255-270.

Deva, Surya/Bilchitz, David (eds.), Building a Treaty on Business and Human Rights: Context and Contours. Cambridge 2017.

Dilling, Olaf, From Compliance to Rulemaking: How Global Corporate Norms Emerge from Interplay with States and Stakeholders. 13 German Law Journal (2012), pp. 381-418. 
Eifert, Martin, Regulierungsstrategien. In: Wolfgang Hoffmann-Riem/Eberhard SchmidtAßmann/Andreas Voßkuhle (eds.), Grundlagen des Verwaltungsrechts. München 2012, pp. 1319-1394.

Eisolt, Dirk, Prüfung von Compliance-Management-Systemen: erste Überlegungen zu IDW EPS 980. Der Betriebs-Berater (BB) 2010, pp. 1843-1848.

Engelhart, Marc, Verfassungsrechtliches Placet für österreichisches Verbandsstrafrecht. Zeitschrift für Wirtschaftsstrafrecht und Haftung im Unternehmen (ZWH) 2018, pp. $165-169$.

- § 130 OWiG. In: Robert Esser/Markus Rübenstahl/Frank Saliger/Michael Tsambikakis, Wirtschaftsstrafrecht. Köln 2017, pp. 1161-1178.

- Corporate Criminal Liability from a Comparative Perspective. In: Dominik Brodowski/Manuel Espinoza de los Monteros de la Parra/Klaus Tiedemann/Joachim Vogel (eds.), Regulating Corporate Criminal Liability. Heidelberg et. al. 2014, pp. 53-76.

- Development and Status of Economic Criminal Law in Germany, 15 German Law Journal (2014), pp. 693-718.

- Paradigmenwechsel im Strafrecht: Die Notwendigkeit einer „Neuen Strafrechtswissenschaft"? Rechtswissenschaft (RW) 2013, pp. 208-215.

- Sanktionierung von Unternehmen und Compliance. Eine rechtsvergleichende Analyse des Straf- und Ordnungswidrigkeitenrechts in Deutschland und den USA. 2nd edn. Berlin 2012.

- Unternehmensstrafbarkeit im europäischen und internationalen Recht, eucrim 2012, pp. 110-123.

- Corporate Criminal Liability and Compliance in Germany. In: Antonio Fiorella/Alfonso Maria Stile (eds.), Corporate criminal liability and compliance programs. First colloquium. Sapienza University of Rome, 12 - 14 May 2011. Napoli 2012, pp. 167-206.

- Die neuen Compliance-Anforderungen der BaFin (MaComp). Zeitschrift für Wirtschaftsrecht (ZIP) 2010, pp. 1832-1840.

- Fateh-Moghadam, Bijan, Criminal Compliance ernst genommen - zur Garantenstellung des Compliance-Beauftragten. In: Georg Steinberg/Brian Valerius/Andreas Popp, (eds.), Das Wirtschaftsstrafrecht des StGB. Baden-Baden 2011, pp. 25-48.

Foucault, Michel, Überwachen und Strafen: Die Geburt des Gefängnisses. Frankfurt a.M. 1976.

Forster, Matthias, Die strafrechtliche Verantwortlichkeit des Unternehmens nach Art. 102 StGB. Bern 2006.

Garland, David, The Culture of Control: Crime and Social Order in Contemporary Society. Oxford 2001.

Geiger, Roman, Organisationsmängel als Anknüpfungspunkt im Unternehmensstrafrecht. Zürich 2006.

Görling, Helmut/Inderst, Cornelia/Bannenberg, Britta (eds.), Compliance - Aufbau, Management, Risikobereiche. Heidelberg u.a. 2010.

Görtz, Birthe/Roßkopf, Michael, Zur Signalwirkung von zertifizierten ComplianceManagement-Systemen. Corporate Compliance Zeitschrift (CCZ) 2011, pp. 103-105. 
Görtz, Birthe, Der neue Compliance-Prüfungsstandard (EPS 980), Inhalte und Aussagen. Corporate Compliance Zeitschrift (CCZ) 2010, pp. 127-133.

Gómez-Jara Díez, Carlos, La culpabilidad de la persona jurídica. In: Bajo Fernández, Miguel/Feijóo Sánchez, Bernardo J./Gómez-Jara Díez, Carlos (eds.), Tratado de responsibilidad penal de las personas jurídicas. 2nd edn. Sine loco 2016, pp. 143-220.

- Grundlagen des konstruktivistischen Unternehmensschuldbegriffes. Zeitschrift für die gesamte Strafrechtswissenschaft (ZStW) 119 (2007), pp. 290-333.

Gruner, Richard S., Corporate criminal liability and prevention. Loose leaf edition, Release 17. New York (New York) 2013.

Hassemer, Winfried, Das Wirtschaftsstrafrecht hat in unseren Tagen Konjunktur: Seine Aufgabe ist Rechtsgüterschutz, nicht Risikobeherrschung. Zeitschrift für Rechtspolitik (ZRP) 2009, pp. 221-222.

Hauschka, Christoph E./Moosmayer, Klaus/Lösler, Thomas, Corporate Compliance. 3rd edn. München 2016.

Hefendehl, Roland, Außerstrafrechtliche und strafrechtliche Instrumentarien zur Eindämmung der Wirtschaftskriminalität. Zeitschrift für die gesamte Strafrechtswissenschaft (ZStW) 119 (2007), pp. 816-847.

- Corporate Governance und Business Ethics: Scheinberuhigung oder Alternativen bei der Bekämpfung der Wirtschaftskriminalität?, Juristenzeitung (JZ) 2006, pp. 119-125.

- Enron, WorldCom, and the Consequences: Business Criminal Law Between Doctrinal Requirements and the Hopes of Crime Policy, 8 Buffalo Law Review (2004), pp. 51-88.

Heine, Günter, Die strafrechtliche Verantwortlichkeit von Unternehmen. Von individuellem Fehlverhalten zu kollektiven Fehlentwicklungen, insbesondere bei Großrisiken. Baden-Baden 1995.

Herschel, Wilhelm, Betriebsbußen. Köln 1967.

Hodges, Christopher, Law and Corporate Behaviour: Integrating Theories of Regulation, Enforcement, Compliance and Ethics. Oxford/Portland 2015.

Hodges, Christopher/Steinholtz Ruth, Ethical business practice and regulation: a behavioural and ethical values-based approach to compliance and enforcement. Oxford/Portland (Oregon) 2017.

Hoffmann-Riem, Wolfgang, Gewährleistungsrecht und Gewährleistungsrechtsprechung am Beispiel regulierter Selbstregulierung. In: Hartmut Bauer/Detlef Czybulka/Wolfgang Kahl (eds.), Wirtschaft im offenen Verfassungsstaat. Festschrift für Reiner Schmidt zum 70. Geburtstag. München 2006, pp. 447-466.

- Administrativ induzierte Pönalisierung. In: Heinz Müller-Dietz/Egon Müller/Karl-Ludwig Kunz et al. (eds.), Festschrift für Heike Jung. Baden-Baden 2007, pp. 299-312.

Hoven, Elisa, Der nordrhein-westfälische Entwurf eines Verbandsstrafgesetzbuchs - Eine kritische Betrachtung von Begründungsmodell und Voraussetzungen der Straftatbestände. Zeitschrift für Internationale Strafrechtsdogmatik (ZIS) 2014, pp. 19-30.

Huck, Winfried/Kurth, Thomas (eds.), Compliance aus dem Blickwinkel des internationalen und europäischen Wirtschaftsrechts - die Extraterritorialität angelsächsischer Embargo- und Strafvorschriften. Hamburg 2013. 
Inderst, Cornelia, Compliance-Organisation in der Praxis. In: Cornelia Inderst/Britta Bannenberg et al. (eds.), Compliance. Aufbau - Management - Risikobereiche. 3rd edn. Heidelberg 2017.

Jaén Vallejo, Manuel/Perrino Peréz, Ángel Luis, La reforma penal de 2015: análisis de las principales reformas introducidas en el código penal por las leyes orgánicas 1 y 2/2015, de 30 de marzo. Madrid 2015.

Javers, Konstanze, Verantwortlichkeit für Straftaten in Unternehmen, Verbänden und andere Kollektiven in Italien. In: Ulrich Sieber/Karin Cornils (eds.), Nationales Strafrecht in rechtsvergleichender Darstellung. Allgemeiner Teil. Vol. 4. Berlin 2008, pp. 408-423.

Jahn, Matthias, Ermittlungen in Sachen Siemens/SEC. Strafverteidiger (StV) 2009, pp. 41-46.

Jentsch, Christiane, Betriebsjustiz. Aachen 2005.

Joseph, Molly E., Organizational Sentencing. 35 American Criminal Law Review (19971998), pp. 1017-1034.

Kaiser, Günther/Metzger-Pregizer, Gerhard (eds.), Betriebsjustiz. Berlin 1976.

Kaplan, Jeffrey M./Murphy, Joseph E., Compliance Programs and the Corporate Sentencing Guidelines. Preventing Criminal and Civil Liability. 2017-2018 edn. Danvers (MA)/Eagan (MN) 2017.

Kasolowsky, Boris/Voland, Thomas, Die OECD-Leitsätze für multinationale Unternehmen und ihre Durchsetzung im Wege von Beschwerdeverfahren vor der Nationalen Kontaktstelle. Neue Zeitschrift für Gesellschaftsrecht (NZG) 2014, pp. 1288-1292.

Katsunori, Kai, Unternehmenstätigkeit und strafrechtliche Sanktionen - Vergleich der Corporate Compliance. In: Harald Baum (ed.), Deutschland und Japan: Zwei Ökonomien im rechtlichen Dialog/Germany and Japan: A Legal Dialogue between Two Economies. Zeitschrift für japanisches Recht, Sonderheft Nr. 6 (2012), pp. 85-105.

Keuper, Frank/Neumann, Fritz, Governance, Risk Management and Compliance. Wiesbaden 2010.

Klinger, Remo/Krajewski, Markus/Krebs, David/Hartmann, Constantin, Verankerung menschenrechtlicher Sorgfaltspflichten von Unternehmen im deutschen Recht. Berlin 2016.

Knierim, Thomas/Rübenstahl, Markus/Tsambikakis, Michael (eds.), Internal Investigations. 2nd edn. Heidelberg 2016.

Kölbel, Ralf, Wirtschaftskriminalität und unternehmensinterne Strafrechtsdurchsetzung. Monatsschrift für Kriminologie und Strafrechtsreform (MschrKrim) 2008, pp. 22-37.

Kölbel, Ralf, Criminal Compliance - ein Missverständnis des Strafrechts? Zeitschrift für die gesamte Strafrechtswissenschaft (ZStW) 125 (2013), pp. 499-535.

Krause, Daniel M., Was bewirkt Compliance? Strafverteidiger-Forum (StraFo) 2011, pp. 437-446.

Krawiec, Kimberly D., Cosmetic Compliance and the Failure of Negotiated Governance. 81 Washington University Law Quarterly (2003), pp. 487-544. 
Kuhlen, Lothar, Grundfragen von Compliance und Strafrecht. In: Lothar Kuhlen/Hans Kudlich/Íñigo Ortiz de Urbina (eds.), Compliance und Strafrecht. Heidelberg et al. 2013, pp. 1-25.

Kuhlmann, Peter, Verbandssanktionierung in Italien. München 2014.

Kutschaty, Thomas, Deutschland braucht ein Unternehmensstrafrecht. Zeitschrift für Rechtspolitik (ZRP) 2013, pp. 74.

Laufer, William S., Corporate Bodies and Guilty Minds: The Failure of Corporate Criminal Liability. Chicago 2006.

La Vega, Connie de, International Standards on Business and Human Rights. Is Drafting a New Treaty Worth It? 51 University of San Francisco Law Review (2017), pp. 431-468.

Lewisch, Peter (ed.), Zauberwort Compliance? Wien 2012.

Liese, Jens/Schulz, Martin; Risikomanagement durch Compliance Audits - Neue Herausforderungen für die Unternehmensorganisation. Der Betriebs-Berater (BB) 2011, pp. $1347-1353$.

Lösler, Thomas, Zu Rolle und Stellung des Compliance-Beauftragten. WertpapierMitteilungen (WM) 2008, pp. 1098-1104.

Lomas, Paul/Kramer Daniel J. (eds.), Corporate Internal Investigations: An International Guide. 2nd edn. Oxford 2013.

Lopez, Carlos/Shea, Ben, Negotiating a Treaty on Business and Human Rights. A Review of the First Intergovernmental Session. 1 Business and Human Rights Journal (2016) (1), pp. 111-116.

Luhmann, Nikolas, Das Recht der Gesellschaft. Frankfurt a. M. 1995.

- Die Wirtschaft der Gesellschaft. Frankfurt a. M. 1994.

Makowicz, Bartosz, Globale Compliance Management Standards. München 2018.

Markoff, Gabriel, Arthur Andersen and the Myth of the Corporate Death Penalty: Corporate Criminal Convictions in the Twenty-First Century. 15 University of Pennsylvania Journal of Business Law (2012-2013), pp. 797-842.

Matthews, Richard, Blackstone's Guide to The Corporate Manslaughter and Corporate Homicide Act 2007. Oxford 2008.

McConnell, Ryan D./Martin, Jay/Simon, Charlotte, Plan Now or Pay Later: The Role of Compliance in Criminal Cases. 33 Houston Journal of International Law (2011), pp. 509-587.

Merkt, Hanno, Überprüfung des Compliance Management Systems zwischen Wirtschaftsprüfern und Juristen, Teil 2. Der Betrieb (DB) 2014, pp. 2331-2337.

Mitsch, Wolfgang, Täterschaft und Teilnahme bei der „Verbandsstraftat”. Neue Zeitschrift für Wirtschafts-, Steuer- und Unternehmensstrafrecht (NZWiSt) 2014, pp. 1-5.

Momsen, Carsten, Internal Investigations zwischen arbeitsrechtlicher Mitwirkungspflicht und strafprozessualer Selbstbelastungsfreiheit. Zeitschrift für Internationale Strafrechtsdogmatik (ZIS) 2011, pp. 508-516.

Moosmayer, Klaus, Compliance. Praxisleitfaden für Unternehmen. 3rd edn. München 2015. 
Moosmayer, Klaus/Sölle, Walter/Toifl, Armin, Das Compliance-Programm von Siemens. In: Alexander Petsche/Karin Mair (eds.), Handbuch Compliance. Wien 2011, pp. 403-412.

Müller, Thomas, Compliance-Management - Dargestellt am Beispiel der Versicherungswirtschaft. Zürich 2007.

Goette, Wulf/Habersack, Mathias, Münchener Kommentar zum Aktiengesetz. 4th edn. München 2016.

Nanda, Ved P., Corporate Criminal Liability in the United States: Is a New Approach Warranted? In: Mark Pieth/Radha Ivory (eds.), Corporate Criminal Liability. Emergence, Convergence, and Risk. Dordrecht 2011, pp. 63-89.

Nieto Martín, Adán, Soziale Verantwortung, corporate governance, Selbstregulierung und Unternehmensstrafrecht. In: Ulrich Sieber/Gerhard Dannecker/Urs Kindhäuser/Joachim Vogel/Tonio Walter (eds.), Strafrecht und Wirtschaftsstrafrecht - Dogmatik, Rechtsvergleich, Rechtstatsachen. Festschrift für Klaus Tiedemann zum 70. Geburtstag. Köln/München 2008, pp. 485-501.

- Grundlegende Probleme von Compliance und Strafrecht. In: Lothar Kuhlen/Hans Kudlich/Íñigo Ortiz de Urbina Gimeno (eds.), Compliance und Strafrecht. Heidelberg 2013, pp. 27-56.

Nisco, Attilio, Verantwortlichkeit juristischer Personen im italienischen Recht. Goltdammer's Archiv für Strafrecht (GA) 2010, pp. 525-534.

Nolde, Malaika, Sanktionen nach der EU-Datenschutz-Grundverordnung, Zeitschrift für Wirtschaftsstrafrecht und Haftung im Unternehmen (ZWH) 2017, pp. 76-82.

O'Brien, Claire Methven/Dhanarajan, Sumithra, The corporate responsibility to respect human rights: a status review. 29 Accounting, Auditing \& Accountability Journal (2016). Vol. 29 Issue: 4, pp. 542-567.

Oesterle, Jörg, Die Beschlagnahme anwaltlicher Unterlagen und ihre Bedeutung für die Compliance-Organisation von Unternehmen. Berlin 2016.

Ortiz de Urbina, Íñigo, Strafrechtliche Sanktionen gegen Unternehmen in Spanien. In: Lothar Kuhlen/Hans Kudlich/Íñigo Ortiz de Urbina (eds.), Compliance und Strafrecht. Heidelberg et al. 2013, pp. 227-244.

Ortmann, Günther, Für ein Unternehmensstrafrecht. Sechs Thesen, sieben Fragen, eine Nachbemerkung. Neue Zeitschrift für Wirtschafts-, Steuer- und Unternehmensstrafrecht (NZWiSt) 2017, pp. 241-288.

Pape, Jonas, Corporate Compliance - Rechtspflichten zur Verhaltenssteuerung von Unternehmensangehörigen in Deutschland und den USA. Berlin 2011.

Parker, Christine/Nielsen, Vibeke, The Challenge of Empirical Research on Business Compliance in Regulatory Capitalism. 5 Annual Review of Law and Social Science (2009), pp. 45-70.

Perrin, Bertrand, La responsabilité pénale de l'entreprise en droit Suisse. In: Mark Pieth/Radha Ivory (eds.), Corporate Criminal Liability. Emergence, Convergence, and Risk. Dordrecht 2011, pp. 193-225.

Perschke, Stefan, Strafrechtliche Sanktionen gegen Unternehmen im US-amerikanischen Recht. In: Uwe Hellmann/Christian Schröder (eds.), Festschrift für Hans Achenbach. Heidelberg 2011, pp. 317-328. 
Pieth, Mark, Anti-Korruptions-Compliance. Praxisleitfaden für Unternehmen. Zürich/St. Gallen 2011.

Pinto, Amanda/Evans, Martin, Corporate Criminal Liability. 3rd edn. London 2013.

Pitt, Harvey L./Groskaufmanis, Karl A., Minimizing Corporate Civil and Criminal Liability: A Second Look at Corporate Codes of Conduct. 78 The Georgetown Law Journal (1989-1990), pp. 1559-1654.

Ramirez, Mary Kreiner, Prioritizing Justice: Combating Corporate Crime from Task Force to Top Priority. 93 Marquette Law Review (2009-2010), pp. 971-1019.

Rödiger, Katja, Strafverfolgung von Unternehmen, Internal Investigations und strafrechtliche Verwertbarkeit von "Mitarbeitergeständnissen": Untersuchung am Beispiel der Siemens-Korruptionsaffäre. Frankfurt a. M. 2012.

Rönnau, Thomas, Strafrecht und Selbstregulierung - Chance oder Risiko? In: Professorinnen und Professoren der Bucerius Law School (eds.), Begegnungen im Recht. Tübingen 2011, pp. 237-258.

Rosenstiel, Lutz, Grundlagen der Organisationspsychologie: Basiswissen und Anwendungshinweise. 6th edn. Stuttgart 2007.

Roth, Monika, Compliance: Begriff, Bedeutung, Beispiele. Basel 2000.

Rotsch, Thomas, Compliance und Strafrecht - Konsequenzen einer Neuentdeckung. In: Wolfgang Joecks/Heribert Ostendorf/Thomas Rönnau/Thomas Rotsch/Roland Schmitz (eds.), Recht - Wirtschaft - Strafe. Festschrift für Erich Samson. Heidelberg et al. 2010, pp. 141-160.

- Criminal Compliance. Zeitschrift für Internationale Strafrechtsdogmatik (ZIS) 2010, pp. 614-617.

- Compliance und Strafrecht - Fragen, Bedeutung, Perspektiven. Zeitschrift für die gesamte Strafrechtswissenschaft (ZStW) 125 (2013), pp. 481-498.

Roxin, Claus, Strafrecht Allgemeiner Teil Band I: Grundlagen. Der Aufbau der Verbrechenslehre. 4th edn. München 2006.

Rübenstahl, Markus, Strafrechtliche Unternehmenshaftung in Italien - das Legislativdekret Nr. 231 vom 8.6.2001. Recht der internationalen Wirtschaft (RIW) 2012, pp. 505-513.

Rübenstahl, Markus/Tsambikakis, Michael, Neues Unternehmensstrafrecht: Der NRWGesetzentwurf zur Einführung der strafrechtlichen Verantwortlichkeit von Verbänden. Zeitschrift für Wirtschaftsstrafrecht und Haftung im Unternehmen (ZWH) 2014, pp. 8-12.

Ruggie, John Gerard, Business and Human Rights: The Evolving International Agenda. 101 American Journal of International Law (2007), pp. 819-840.

Ruggie, John Gerard/Nelson, Tamaryn, Human Rights and the OECD Guidelines for Multinational Enterprises. Normative Innovations and Implementation Challenges. 22 Brown Journal of World Affairs (2015), pp. 99-128.

Saliger, Frank, Grundfragen von Criminal Compliance. Rechtswissenschaft (RW) 2013, pp. 263-291.

- Privatisierung im Strafrecht. In: Professorinnen und Professoren der Bucerius Law School (eds.), Begegnungen im Recht. Tübingen 2011, pp. 215-235. 
Schmidt-Husson, Franck G., § 6. Delegation von Organpflichten. In: Christoph E. Hausch$\mathrm{ka} /$ Klaus Moosmayer/Thomas Lösler (eds.), Corporate Compliance. 3rd edn. München 2016, pp. 114-136.

Schober, Katharina, Der Zweck im Verwaltungsrecht. Tübingen 2007.

Schünemann, Bernd, Die aktuelle Forderung eines Verbandsstrafrechts - Ein kriminalpolitischer Zombie. Zeitschrift für Internationale Strafrechtsdogmatik (ZIS) 2014, pp. 1-18.

Schulz, Wolfgang/Held, Thorsten, Regulierte Selbstregulierung als Form modernen Regierens. Hamburg 2002.

Sieber, Ulrich, Compliance-Programme im Unternehmensstrafrecht. Ein neues Konzept zur Kontrolle von Wirtschaftskriminalität. In: Ulrich Sieber/Gerhard Dannecker/Urs Kindhäuser/Joachim Vogel/Tonio Walter (eds.), Strafrecht und Wirtschaftsstrafrecht Dogmatik, Rechtsvergleich, Rechtstatsachen. Festschrift für Klaus Tiedemann zum 70. Geburtstag. Köln/München 2008, pp. 449-484.

- Grenzen des Strafrechts. Grundlagen und Herausforderungen des neuen strafrechtlichen Forschungsprogramms am Max-Planck-Institut für ausländisches und internationales Strafrecht. Zeitschrift für die gesamte Strafrechtswissenschaft (ZStW) 119 (2007), pp. 1-68.

- Legal Regulation, Law Enforcement and Self-Regulation - A new Alliance for Preventing Illegal and Harmful Contents in the Internet. In: Jens Waltermann/Marcel Machill (eds.), Protecting Our Children on the Internet - Towards a New Culture of Responsibility. Gütersloh 2000, pp. 319-399.

- Rechtliche Ordnung in einer globalen Welt. Rechtstheorie 41 (2010), pp. 151-198.

Sieber, Ulrich/Engelhart, Marc, Compliance Programs for the Prevention of Economic Crimes in Germany - An Empirical Survey. Berlin 2014.

Sigler, Jay A./Murphy, Joseph E., Interactive corporate compliance: an alternative to regulatory compulsion. New York 1988.

Singelnstein, Tobias, Strafrecht und neoliberales Regieren - Entwicklungstendenzen des Strafrechts als Einschreibung von Regierungstechniken im Sinne der Gouvernementalität. Kritische Justiz (KJ) 2011, pp. 7-15.

Spieß, Erica/Winterstein, Hans, Verhalten in Organisationen: eine Einführung. Stuttgart 1998.

Spindler, Gerald/Stilz, Eberhard, Kommentar zum Aktiengesetz. 3rd edn. München 2015.

Staffler, Lukas, Criminal Compliance. Vorgaben in Spanien nach der Reform von 2015. Zeitschrift für Wirtschafts- und Finanzstrafrecht (ZWF) 2017, pp. 241-244.

Staffler, Lukas, Sanktionsrechtliche Anreize im VbVG für Implementation bzw. Verbesserung von Criminal Compliance-Maßnahmen. Journal für Strafrecht (JSt) 2016, pp. 500-505.

Staffler, Lukas, Bestimmtheit von Compliance-Anforderungen für Verbände: Lösungsansätze im romanischen Rechtskreis. Journal für Strafrecht (JSt) 2017, pp. 320-325.

Steinberg, Richard M., Governance, Risk Management, and Compliance: It Can't Happen to Us - Avoiding Corporate Disaster While Driving Success. Hoboken (New Jersey) 2011.

Steßl, Antonia, Effektives Compliance Management in Unternehmen. Wiesbaden 2012. 
Taguchi, Morikazu, 'Criminal Proceedings of Corporate Crime'. In: Morikazu Taguchi/Katsunori Kai/Takeyoshi Shiraishi (eds.), Corporate Crime and Compliance Programs. Tokyo 2007, pp. 231-269 [in Japanese].

Tauschwitz, Moritz/Tornero, José, Die Kodifizierung von Compliance - Zur Strafbarkeit juristischer Personen in Spanien nach der Reform von Art. 31 Código Penal. Corporate Compliance Zeitschrift (CCZ) 2016, pp. 18-21.

Teubner, Gunther, Global law without a state. Dartmouth 1997.

Theile, Hans, Unternehmensrichtlinien - ein Beitrag zur Prävention von Wirtschaftskriminalität? Zeitschrift für Internationale Strafrechtsdogmatik (ZIS) 2008, pp. 406-418.

Theile, Hans/Gatter, Marcelle Janina/Wiesenack, Tobias C., Domestizierung von Internal Investigations? Zeitschrift für die gesamte Strafrechtswissenschaft (ZStW) 126 (2014), pp. 803-843.

Tiedemann, Klaus, Wirtschaftsstrafrecht. 5th edn. München 2017.

- Corporate Criminal Liability as a Third Track. In: Dominik Brodowski/Manuel Espinoza de los Monteros de la Parra/Klaus Tiedemann/Joachim Vogel (eds.), Regulating Corporate Criminal Liability. Heidelberg et. al. 2014, pp. 11-18.

- Wirtschaftsstrafrecht und Wirtschaftskriminalität. Vol 1: Allgemeiner Teil. Reinbek bei Hamburg 1976.

Vogel, Joachim, Wertpapierhandelsstrafrecht - Vorschein eines neuen Strafrechtsmodells? In: Michael Pawlik/Rainer Zaczyk (eds.), Festschrift für Günther Jakobs zum 70. Geburtstag am 26. Juli 2007. Köln et al. 2007, pp. 731-746.

von Lentzke, Manfred, Betriebsjustiz. Köln 1972.

Voßkuhle, Andreas, „Schlüsselbegriffe“ der Verwaltungsrechtsreform - eine kritische Bestandsaufnahme. Verwaltungsarchiv, Vol. 92 (2001), pp. 184-215.

Waldhoff, Christian, Vollstreckung und Sanktionen. In: Wolfgang Hoffmann-Riem/Eberhard Schmidt-Aßmann/Andreas Voßkuhle (eds.), Grundlagen des Verwaltungsrechts. München 2009, pp. 269-423.

Walsh, Charles J./Pyrich, Alissa, Corporate Compliance Programs as a Defense to Criminal Liability: Can a Corporation Save Its Soul? 47 Rutgers Law Review (1994-1995), pp. 605-691.

Webb, Dan K./Tarun, Robert W./Molo, Steven F., Corporate internal investigations. New York 2017.

Wessing, Jürgen, Compliance - oder wie sich der Staat aus der Kriminalprävention stiehlt. In: Winfried Hassemer/Eberhard Kempf/Sergio Moccia (eds.), In dubio pro libertate Festschrift für Klaus Volk zum 65. Geburtstag. München 2009, pp. 867-884.

- Braucht Deutschland ein Unternehmensstrafrecht? Zeitschrift für Wirtschaftsstrafrecht und Haftung im Unternehmen (ZWH) 2012, pp. 301-305.

Wetzel, Julia Ruth-Maria, Human Rights in Transnational Business. Translating Human Rights Obligations into Compliance Procedures. Cham 2016.

Wewerka, Frederike, Internal Investigations: Private Ermittlungen im Spannungsfeld von strafprozessualen Grundsätzen und Anforderungen eines globalisierten Wirtschaftsstrafverfahrens. Frankfurt a. M. 2012. 
Zabel, Benno, Kulturen der Kontrolle. Zum Risiko- und Konfliktmanagement des modernen Rechtsstaates. Kritische Vierteljahresschrift für Gesetzgebung und Rechtswissenschaft (KritV) 2011, pp. 18-37.

Zerbes, Ingeborg, Unternehmensinterne Untersuchungen. Zeitschrift für die gesamte Strafrechtswissenschaft (ZStW) 125 (2013), pp. 551-572.

Ziegleder, Diana, Wirtschaftskriminalität im Geschäftsleben. Eine empirische Untersuchung formeller und informeller Handlungsstrategien von Unternehmen am Beispiel Deutschlands. Berlin 2002. 
Over the past two decades, companies have been increasingly implementing programs in order to achieve better compliance with legal and non-legal regulations and to facilitate the detection of respective infringements. These compliance programs not only promise to reduce crime and improve the companies' reputations. They are also gaining legal relevance, since they are required by law in specific areas, and they can eliminate or reduce the criminal liability of companies when employees infringe legal provisions (corporate crime). Compliance is therefore part of a new discussion on legal approaches in the global risk society, where private and public spheres merge more closely in order to enhance their efforts against (transnational) economic crime. This contribution depicts the compliance development in criminal law and surrounding areas, analyses the different levels of regulated self-regulation, and sketches the outlines of an umbrella compliance theory.

ArchiS - Architektur des Sicherheitsrechts

c/o Max-Planck-Institut für ausländisches

und internationales Strafrecht

Günterstalstr. 73

79100 Freiburg i. Br.

Germany

Tel. +49 (761) 7081-1

Fax +49 (761) 7081-294

info@mpicc.de

http://www.mpicc.de

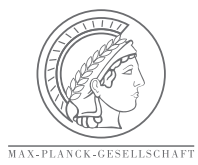

